\title{
EL DELITO DE ASESORAMIENTO Y DE ACTIVIDAD PROFESIONAL INCOMPATIBLE CON LA FUNCIÓN PÚBLICA
}

\author{
Luis Roca de Agapito*
}

Resumen: El conflicto de intereses está en la base de muchos casos de corrupción de empleados públicos. Dado el actual fracaso de los mecanismos administrativos de control y sanción de los mismos, considero que la intervención penal en este terreno está justificada. Si bien, para establecer una precisa distinción entre el ilícito administrativo y el ilícito penal, en el trabajo llevo a cabo una interpretación teleológica y valorativa de todos los elementos del artículo 441 del Código penal, concluyendo que la desaprobación penal de la actividad profesional o de asesoramiento incompatible con la función pública se determinará por la finalidad a la que sirve, que es la de obtener o conceder una ventaja frente a los demás ciudadanos, poniendo así en peligro la imparcialidad de los empleados públicos y por ende la objetividad de los poderes públicos.

Palabras clave: imparcialidad de empleados públicos, objetividad de los poderes públicos, conflicto de intereses, incompatibilidades, actividad profesional o asesoramiento punibles.

Recibido: octubre 2017. Aceptado: noviembre 2018

* Titular de Derecho Penal.

Departamento de Ciencias Jurídicas Básicas. Facultad de Derecho de la Universidad de Oviedo. Calle Valentín Andrés Álvarez, s/n, 33001 Oviedo. Email: luisroca@uniovi.es 


\begin{abstract}
Many cases of public employee corruption are based on conflicts of interest. Given the current failure of control and punishment with administrative mechanisms, I consider that the criminal intervention in this field is justified. Although, in order to establish a precise distinction between administrative and criminal offences, I have carried out a teleological and qualitative interpretation of all elements of article 441 of the Criminal Code, concluding that criminal disapproval of professional activity or advice incompatible with the public function will be determined by the purpose that serves, which is to obtain or grant an advantage over other citizens, thus risking the impartiality of public employees and therefore the objectivity of public powers.

Keywords: impartiality of public employees, public powers objectivity, conflicts of interest, incompatibilities, counseling or professional activity punishable.
\end{abstract}

"Nadie puede servir a dos señores" (Mateo 6, 24)

\title{
1. Introducción
}

"La integridad de los cargos y empleados públicos puede ser puesta en tela de juicio por la existencia de conflictos de intereses que mal gestionados pueden dar lugar a casos de corrupción. Para hacerles frente, la legislación incorpora diferentes mecanismos y diseña diversos procedimientos que de una manera más o menos directa persiguen evitar conflictos de intereses y tratan de luchar contra la corrupción"1. Entre estos mecanismos

1 Así comienza el trabajo de Cerrillo i Martínez, A.: "Los conflictos de intereses y los pactos de integridad: la prevención de la corrupción en los contratos públicos", en M. Villoria Mendieta/J.M. Gimeno Feliú/J. Tejedor Bielsa (dirs.): La corrupción en España. Ámbitos, causas y remedios jurídicos, Barcelona, 2016, p. 185, entendiendo la integridad no como una dignidad u honorabilidad en el cargo, sino como "la coherencia y la congruencia entre los valores y principios que guían la actuación de los cargos y empleados públicos y su actuación”. Más extensamente, IDEM, 
preventivos se encuentra el régimen de incompatibilidades de los empleados públicos, y para garantizar que éste no se rebaje a una mera recomendación ética, el Derecho ha previsto diversas sanciones para el caso de su incumplimiento, que en los casos más graves puede dar lugar incluso a una respuesta penal.

En efecto, el legislador penal ha previsto que el ejercicio privado de actividades incompatibles con el desempeño de un cargo público pueda ser constitutivo de delito dentro del Cap. IX «De las negociaciones y actividades prohibidas a los funcionarios públicos y de los abusos en el ejercicio de su función» del Tít. XIX del Lib. II del CP. Se refieren a dicho tipo de conductas fundamentalmente los arts. 439 y 441 CP. De las dos figuras mencionadas, una, el art. $439 \mathrm{CP}$, que castiga la participación en negocios o actuaciones en los que el funcionario se debe abstener, y otra, el art. $441 \mathrm{CP}$, que sanciona el llevar a cabo una actividad profesional o de asesoramiento incompatible con el empleo público, yo voy a centrarme exclusivamente en esta última.

En los textos legales precedentes, ya desde el primero de nuestros Códigos (arts. 479-482 CP/1822), se preveía la actual figura la participación lucrativa en negocios en los que el funcionario debía abstenerse. Entonces se decía: «mezclarse directa o indirectamente en operaciones de agio, tráfico o granjería dentro de los límites de su jurisdicción o mando» (art. 460-461 CP/1848; 415 CP/1870; 493 CP/1928; 409 CP/1932; 404 CP/1944). Ahora el art. $439 \mathrm{CP} / 1995$ castiga el «forzar o facilitarse cualquier forma de participación... en tales negocios [contrato, asunto, operación o actividad en los que debe intervenir por razón de su cargo] $\rangle^{2}$.

Pero el antecedente del actual delito de asesoramiento o de actividad profesional incompatible con la función pública del art. $441 \mathrm{CP}$ se encuentra inicialmente en el art. $221 \mathrm{CP} / 1932$, que sólo se refería a los «Ministros de la República», y en el art. 198

El principio de integridad en la contratación pública. Mecanismos para la prevención de los conflictos de intereses y la lucha contra la corrupción, Cizur Menor, 2014.

2 Sobre esta figura, véase, por todos, JAREÑo LeAL, A.: El delito de negociaciones prohibidas a los funcionarios públicos, Cizur Menor, 2015. 
CP/1944, que comprendería ya cualquier «autoridad o funcionario público». En dicho artículo se penaba con inhabilitación especial y multa a quien, «prevaliéndose de su cargo, ejerciere alguna profesión directamente relacionada con la esfera de sus atribuciones oficiales, o interviniere directa o indirectamente en empresas o asociaciones privadas con móvil de lucro» ${ }^{3}$.

La redacción actual del delito de asesoramiento o de actividad profesional incompatible con la función pública tiene su origen en la normativa franquista relativa a las incompatibilidades de los funcionarios. Más exactamente en el art. 1.2 ${ }^{\mathrm{a}}$ del Decreto-Ley de 13 de mayo de 1955, sobre incompatibilidades de funcionario de la Administración Civil del Estado ( $B O E$ $\mathrm{n}^{\mathrm{o}}$ 149, 29 mayo 1955, p. 3256). Conviene recordar que tras la Guerra Civil la versión oficial justificó la proliferación de pluriempleos, tanto en lo público como en lo privado, por circunstancias excepcionales. Así, Serrano Guirado hablaba de un "período de cierta benignidad y tolerancia anterior al Decreto-ley... [justificado, entre otras razones, por] las circunstancias de emergencia económica del país...; [y] la necesidad de disponer de un personal idóneo, experto y de confianza, para el ejercicio de determinadas funciones"4, en otras palabras, de afinidad política, pues no hay que olvidar la enorme purga que se produjo tras la victoria del alzamiento nacional. "Superadas esas circunstancias de excepción -continuaba más abajo-, se hacía necesaria la revisión de las situaciones, restableciéndose la vigencia del principio de incompatibilidad, como rector de un propósito político en la materia y de un régimen de la función pública". Con posterioridad, dicho precepto se incorporaría al art. 83.2 de la Ley de Funcionarios Civiles del Estado (aprobada por el Decreto 315/1964, de 7 de febrero) (BOE $\mathrm{n}^{\circ}$ 40, 15 febrero 1964, p. 2052).

Estos antecedentes fueron los que dieron lugar al art. 493 del Proyecto de Código Penal de $1980^{5}$, cuya redacción se mantuvo prácticamente inalterada en los Proyectos de 1992 (art. 421) y

3 Más detalles en Delgado Gil, A.: Delitos cometidos por funcionarios públicos. Negociaciones prohibidas, actividades incompatibles y uso indebido de secreto o información privilegiada, Valencia, 2008, p. 57 ss.

4 Serrano Guirado, E.: "Las incompatibilidades de autoridades y funcionarios”, en Revista de Administración Pública n 19 (1956), p. 84.

5 Mir PUIG, S.: "Nombramientos ilegales, negociaciones y actividades prohibidas a los funcionarios públicos y abusos en el ejercicio de su función", 
de 1994 (art. 419), y de ahí pasó al presente art. 441 CP/1995, sin que durante la tramitación parlamentaria se presentase enmienda alguna. De aquella redacción del PCP/1980 únicamente ha variado la duración de la pena de suspensión, que inicialmente era de 2 a 6 años, pero luego se rebajó a una de 1 a 3 años en el PCP/1992, y es la que llegó al CP/1995, si bien después se elevaría por la LO 1/2015, de 30 de marzo. Tampoco se recogió la previsión del PCP/1980 de que en caso de reincidencia, en lugar de la pena de suspensión, se impusiese la de inhabilitación especial por tiempo de 6 a 18 años.

En el Derecho comparado también existen preceptos que sancionan penalmente los conflictos de intereses en que puedan incurrir los funcionarios debido al ejercicio de una actividad profesional o de asesoramiento incompatible ${ }^{6}$, como por ejemplo los arts. 432-13 Code pénal francés, 245 Code pénal belga, 323 Codice penale italiano, 18 U.S. Code $§ 208$.

\section{La redacción actual del art. 441 CP dice así:}

«La autoridad o funcionario público que, fuera de los actos admitidos en las leyes o reglamentos, realizare, por sí o por persona interpuesta, una actividad profesional o de asesoramiento permanente o accidental, bajo la dependencia o al servicio de entidades privadas o de particulares, en asunto en que deba intervenir o haya intervenido por razón de su cargo, o en los que se tramiten, informen o resuelvan en la oficina o centro directivo en que estuviere destinado o del que dependa, incurrirá en las penas de multa de seis a doce meses y suspensión de empleo o cargo público por tiempo de dos a cinco años».

en Cuadernos de Derecho Judicial n ${ }^{\circ} 30$ («Los delitos de los funcionarios públicos en el Código Penal de 1995») (dir. J.L. González Cussac), Madrid, 1996, p. 319, quien además señalaba que "constituía un progreso el hecho de reunir en un mismo lugar sistemático dos preceptos que poseían una misma naturaleza". Ya antes en Mir Puig, S.: "Negociaciones prohibidas a los funcionarios”, en Nueva Enciclopedia Jurídica, t. XVII, Barcelona, 1982, p. 202.

6 Véase, entre otros, Nieto Martín, A.: "Conflicto de intereses y transparencia (art. 8)", en L. Arroyo Zapatero/A. Nieto Martín (coords.): Fraude y corrupción en el Derecho penal económico europeo. Eurodelitos de corrupción y fraude, Cuenca, 2006, p. 103 ss. No obstante, este autor considera que "pese a que... es común la existencia de una copiosa normativa administrativa, la intervención del derecho penal en este sector es mucho más comedida y menos uniforme que en los delitos de corrupción en sentido estricto" (p. 110). 


\section{EI conflicto de intereses como presupuesto de la incompatibilidad punible}

Antes de entrar en el análisis de este precepto, hay que decir que el presupuesto que está en la base del mismo es la existencia de un conflicto de intereses entre los particulares del funcionario y los generales de la Administración ${ }^{7}$. El funcionario, en una especie de desdoblamiento de la personalidad, al realizar la conducta descrita en el art. 441 CP se guía por la consecución de unos intereses personales, mientras que, según el art. 103.1 CE, «la Administración sirve con objetividad los intereses generales». Es por ello por lo que el art. 103.3 CE también establece que los funcionarios deben actuar con imparcialidad. Asimismo, también aparece recogido este deber de imparcialidad entre los principios éticos que integran el Código de conducta de los empleados públicos, concretamente en los apartados $\mathbf{2}$ y 5 del art. 53 Estatuto Básico del Empleado Público (aprobado por el RD-Legislativo 5/2015, de 30 de octubre). Por tanto, objetividad de la Administración e imparcialidad de los funcionarios son conceptos que van de la mano, que en buena medida se superponen, aunque en el plano teórico podamos distinguirlos en función del sujeto al que se refieren ${ }^{8}$.

7 Cabe señalar que un conflicto de intereses también puede aparecer en ámbitos exclusivamente privados, y existen normas muy diversas que tratan de evitarlos. Por ejemplo, en el ámbito societario: el art. 229 Ley de Sociedades de Capital (texto refundido aprobado por el RD-Legislativo 1/2010, de 2 de julio); o en el ámbito familiar: los arts. 162, 221, 299 CC; o en el ámbito de la mediación: el art. 13 de la Ley 5/2012, de 6 de julio, de mediación en asuntos civiles y mercantiles. Incluso en algunos casos, el conflicto de intereses privados está en la base de otros delitos, como el delito de deslealtad del abogado del art. 467.1 CP, por ejemplo.

8 Es significativo en este sentido el título que pone GarCÉs CARBonell a su trabajo: "La imparcialidad u objetividad como bien jurídico protegido en el delito del artículo 441 del Código Penal”, en Foro FICP n 2013-2, p. 301 ss. Precisamente el primer epígrafe de este trabajo comienza así: "A fin de que adquiera plena realidad el mandato del artículo 103.1 de la Constitución, según el cual la Administración 'sirve con objetividad los intereses generales', el ejercicio de sus funciones públicas por las autoridades y funcionarios públicos ha de estar presidido por la imparcialidad". 
El conflicto de intereses puede surgir fácilmente por haber desarrollado una actividad profesional privada con anterioridad al acceso a la función pública, también puede aparecer, como es lógico, porque la lleve a cabo durante el desempeño de la función pública, e incluso se puede producir igualmente después de haber cesado en el ejercicio de las funciones públicas.

Aunque hay quien pueda ver algo positivo en lo que comúnmente se conoce como puertas giratorias, revolving doors (en inglés) o pantouflage (en francés) ${ }^{9}$, sin embargo, el nombramiento de ejecutivos de empresas para ocupar cargos públicos y puestos claves en el gobierno, y a la inversa, la colocación de políticos en los consejos de administración de las grandes empresas, abre la posibilidad de que la elaboración de políticas y la aplicación de las normas se inclinen hacia esos sectores empresariales para darles ventajas ${ }^{10}$. Y es que el pastel es lo suficien-

Véase también al respecto, el monográfico dedicado a «El principio de objetividad», en Documentación Administrativa n $^{\circ} 289$ (2011), y en particular, GARCía CostA, F.M.: "Delimitación conceptual del principio de objetividad: objetividad, neutralidad e imparcialidad", p. 21 ss.

9 Véase, por ejemplo, la entrevista a Carmen BeCERril Martínez (Consejera de Acciona desde 2014, antes Presidenta de la Fundación Acciona Microenergía desde 2007, y antes Directora de Consultoría Estratégica del Sector de Energía en PricewaterhouseCoopers desde 2004, puesto que ocupó nada más abandonar el sector público: RD 1095/2004, de 7 de mayo, por el que se dispone el cese como Directora General de Política Energética y Minas), publicada en la revista Consejeros: La revista del buen gobierno y la responsabilidad corporativa $\mathrm{n}^{\circ} 116$ (mayo 2016) (disponible en www. revistaconsejeros.com).

10 Un ejemplo de lo que en mi opinión constituyen este tipo de decisiones políticas puede ser el llamado peaje de respaldo, más conocido como el "impuesto al sol", establecido por el RD 900/2015, de 9 de octubre, por el que se regulan las condiciones administrativas, técnicas y económicas de las modalidades de suministro de energía eléctrica con autoconsumo y de producción con autoconsumo (BOE $\mathrm{n}^{\circ} 243,10$ octubre 2015, p. 94874 ss.). El Defensor del Pueblo se pronunció en contra de su implantación. Sin embargo, el Ministerio de Industria, entonces ocupado por José Manuel SoRIA LóPEz, hizo caso omiso. Cfr. la Recomendación del Defensor del Pueblo de 4 de julio de 2014, sobre el establecimiento de un peaje a la producción de energía eléctrica de autoconsumo (disponible en www.defensordelpueblo.es). Téngase en 
temente jugoso como para no querer intervenir en su reparto ${ }^{11}$, por lo que no es de extrañar, como decía, que a las empresas les interese "colocar" en altos cargos a empleados suyos o al revés a políticos en sus consejos de administración con el fin de sacar el máximo rédito económico ${ }^{12}$.

La actividad profesional pretérita puede cuestionar la imparcialidad del empleado público y por eso surge el deber de abstenerse, que con carácter general está previsto en el art. 23.2 letra e) Ley 40/2015, de 1 de octubre, de Régimen Jurídico del Sector Público, así como específicamente para los altos cargos en el art. 12.1 Ley 3/2015, de 30 de marzo, reguladora del ejercicio del alto cargo de la Administración General del Estado. Paralelamente al deber de abstención se prevé también el derecho de recusación de los interesados (art. 24 Ley 40/2015), pues no en vano el correlato de la imparcialidad de los funcionarios y de la objetividad de la Administración es la igualdad de los ciudadanos ante ella ${ }^{13}$.

cuenta también que el Código Técnico de la Edificación obliga a establecer unas exigencias básicas de ahorro de energía HE 4 y HE 5 (véase el art. 15 RD 314/2006, de 17 de marzo; y la Orden FOM/1635/2013, de 10 de septiembre, que lo desarrolla). El peaje de respaldo ha sido avalado por la STS, Sala C-A (Secc. $3^{\mathrm{a}}$ ), $\mathrm{n}^{\mathrm{o}}$ 1542/2017, de 13 de octubre.

11 Por ejemplo, la OCDE cuantifica en 4,2 billones de euros el presupuesto gastado por los países miembros en contratos administrativos. Véase OCDE, Preventing Corruption in Public Procurement, 2016, p. 5 (disponible en www.ocde.org). Según esta estimación, la actividad gubernamental de compra de bienes, servicios y obras representó el 12\% del PIB y el $29 \%$ de los gastos de las Administraciones públicas de los países de la OCDE.

La Comisión Europea, en la Comunicación de 6 de junio de 2011, relativa a la Lucha contra la corrupción en la UE [COM(2011) 308 final] afirma que "todos los años se pierd[e]n unos 120.000 millones EUR, un uno por ciento del PIB de la UE, por causa de la corrupción” (p. 3).

12 Esclarecedor al respecto, Juste DE ANCos, R.: Ibex 35, una historia herética del poder en España, Madrid, 2017.

13 Como dice Mir Puig, $C D J \mathrm{n}^{\circ} 30$ (1996), p. 324: "Estos delitos ponen en cuestión la imparcialidad de la Administración al resolver asuntos que pueden afectar a los ciudadanos y/o la igualdad de oportunidades de funcionarios y ciudadanos a la hora de obtener determinados beneficios eco- 
En particular, el art. 11 Ley 3/2015 ofrece una definición de conflicto de intereses, según la cual un alto cargo «está incurso en conflicto de intereses cuando la decisión que vaya a adoptar... pueda afectar a sus intereses personales, de naturaleza

nómicos", pero inmediatamente a continuación aclara que: "La participación indebida en negocios y el ejercicio profesional incompatible comprometen en primer lugar la imparcialidad de resoluciones de la Administración que alcanzan a ciudadanos".

El propio Santiago Mir PuIG, bajo la vigencia del anterior Código, daba una visión más crematística del bien jurídico, por cuanto que "no es tanto el funcionamiento técnico de la máquina administrativa lo que resulta en él afectado, sino el interés que la sociedad posee en que ciertos funcionarios permanezcan alejados del mundo de intereses y expectativas de ganancias particulares que implica el entrar en negocios lucrativos, intereses y expectativas particulares necesariamente incompatibles con el carácter jurisdiccional o de gobierno de tales funcionarios, en cuanto podrían condicionar la adopción de resoluciones partidistas o la orientación de la acción pública al servicio de su enriquecimiento personal... La función pública resultaría enturbiada si sus funcionarios se sirviesen de ella para fines particulares de lucro. La pureza de la Administración requiere su imparcialidad en los negocios privados" [NEJ t. XVII (1982), p. 203].

Por su parte, Delgado Gil considera que "no se trata únicamente... de que el funcionario ha de comportarse con objetividad e imparcialidad para que todos los ciudadanos puedan ser iguales en relación con el ejercicio de la actividad pública; significa también que todos, también los funcionarios, han de ser iguales ante la ley, sin que pueda prevalecer la condición de autoridad o funcionario público" [Delgado Gil, Delitos cometidos por funcionarios públicos..., cit., p. 60; IDEM, "El necesario ánimo de obtener un beneficio económico y el "asesoramiento" en el delito de actividades incompatibles a los funcionarios públicos. (A propósito de la STS 25 de enero de 2010)", en La Ley penal $\mathrm{n}^{\circ} 75$ (2010), p. 75]. Idéntica Garcés CARBonell, Foro FICP $\mathrm{n}^{\circ} 2013-2$, p. 305, sin ninguna cita al respecto.

Valga como ejemplo la STS 1048/1997, de 18 de julio, que condenó por el delito del art. $198 \mathrm{CP} / 1944$ a un Alcalde que "se beneficiaba de las ventajas que proporcionaba su cargo para obtener las licencias solicitadas por sus empresas con una inusitada celeridad, presionando para ello a los funcionarios municipales, administrativos y técnicos..., hasta el punto de que, en ocasiones, la licencia se solicitó en un día determinado y, se incoó el expediente, se dio traslado para informe a los servicios técnicos, se emitió dictamen por el Aparejador Municipal, se reconvocó a la Comisión de Gobierno, se celebró la reunión tan rápidamente convocada y se concedió la licencia solicitada, todo ello en el mismo día... Alega el recurrente que la agilidad administrativa no es delictiva y debería ser digna de alabanza, 
económica o profesional, por suponer un beneficio o un perjuicio a los mismos» $\rangle^{14}$. Pero esta definición legal resulta discutible por la limitación que supone de su ámbito de operatividad ${ }^{15}$. Apartándose de lo que se suele establecer a nivel internacional ${ }^{16}$, ha restringido su ámbito en un doble sentido. Por un lado, porque considera que el conflicto sólo surge cuando el alto cargo tenga que tomar una decisión ${ }^{17}$, aunque esto no se entienda en

pero dicha alabanza se torna en reproche cuando se aprecia que tan pasmosa celeridad no se aplica imparcialmente al conjunto de los administrados, sino únicamente a las solicitudes de las empresas del Alcalde, en cuya tramitación y resolución, por cierto, tenía éste obligación legal de abstenerse y no lo hacía".

14 Asimismo se concreta que «se consideran intereses personales: a) Los intereses propios. b) Los intereses familiares, incluyendo los de su cónyuge o persona con quien conviva en análoga relación de afectividad y parientes dentro del cuarto grado de consanguinidad o segundo grado de afinidad. c) Los de las personas con quien tenga una cuestión litigiosa pendiente. d) Los de las personas con quien tengan amistad íntima o enemistad manifiesta. e) Los de personas jurídicas o entidades privadas a las que el alto cargo haya estado vinculado por una relación laboral o profesional de cualquier tipo en los dos años anteriores al nombramiento. f) Los de personas jurídicas o entidades privadas a las que los familiares previstos en la letra b) estén vinculados por una relación laboral o profesional de cualquier tipo, siempre que la misma implique el ejercicio de funciones de dirección, asesoramiento o administración»».

15 Véase, con ulteriores referencias, Cerillo i Martínez, A.: "La oportunidad perdida en la prevención de los conflictos de intereses en la Administración General del Estado. Un breve análisis de la Ley 3/2015, de 30 de marzo", en Eunomía $\mathrm{n}^{\mathrm{o}} 12$ (2017), p. 77 ss.

16 Cfr., por ejemplo, con el art. 24 de la Directiva 2014/24/UE, del Parlamento Europeo y del Consejo, de 26 de febrero de 2014, sobre contratación pública, que habla de «cualquier situación...»; o con la del apart. 10 de las $O E C D$ Guidelines for Managing Conflict of Interest in the Public Service, que se refiere en general al «desempeño de sus funciones y responsabilidades oficiales».

17 El precedente inmediato del actual art. 11 Ley 3/2015, el art. 4.1 de la Ley $5 / 2006$, de 10 de abril, de regulación de los conflictos de intereses de los miembros del Gobierno y de los Altos Cargos de la Administración General del Estado, también circunscribía el conflicto a cuando «intervienen en las decisiones». En este sentido puede citarse también el art. 2 de la Ley 1/2008, de 2 de julio, reguladora de los conflictos de intereses de los Miembros del 
términos estrictos (art. 15.3 Ley 3/2015). Y por otro, porque literalmente se dice que el conflicto de intereses sólo puede ser de naturaleza económica o profesional ${ }^{18}$. Por el contrario, otras definiciones son más amplias y se refieren a cualquier situación y no únicamente a cuando se tome una decisión, ni tampoco a que los intereses tienen que ser exclusivamente económicos ${ }^{19}$. En mi opinión, este concepto amplio de conflicto de intereses es el que se encuentra en la base del art. $441 \mathrm{CP}^{20}$.

Con posterioridad al desempeño de la función pública también puede aparecer un conflicto de intereses, pues exis-

Gobierno y de los Altos Cargos de la Administración de Cantabria; el art. 34 de la Ley 4/2011, de 31 de marzo, de la buena administración y del buen gobierno de las Illes Balears; el art. 53 de la 12/2014, de 16 de diciembre, de Transparencia y Participación Ciudadana de la Comunidad Autónoma de la Región de Murcia; el art. 62 de la Ley Foral de Navarra 11/2012, de 21 de junio, de la Transparencia y del Gobierno Abierto; el art. 9 de la Ley del País Vasco 1/2014, de 26 de junio, Reguladora del Código de Conducta y de los Conflictos de Intereses de los Cargos Públicos.

18 Todavía más categórico en este sentido es el art. 1.3 de la Ley de la Comunidad Valenciana 8/2016, de 28 de octubre, de Incompatibilidades y Conflictos de Intereses de Personas con Cargos Públicos no Electos, que se refiere a un «ánimo de lucro pecuniario o en especie».

19 Así, véase el art. 8 de la Ley 3/2016, de 30 de noviembre, del Estatuto de los Altos Cargos de la Administración de la Comunidad de Castilla y León; o el art. 43 de la Ley de Galicia 1/2016, de 18 de enero, de transparencia y buen gobierno.

20 Por el contrario, otros autores son mucho más restrictivos en la delimitación del conflicto de intereses. Así, entre otros, Nieto Martín, Eurodelitos de corrupción y fraude..., cit., p. 115-116, utiliza cuatro parámetros para perfilar la intervención penal en esta materia: 1) El sujeto activo, que lo limita a los altos cargos; 2) El grado del conflicto de intereses, si potencial/aparente o real/actual, limitándolo al real; 3) La naturaleza del conflicto, que debe ser exclusivamente económico; y 4) La intensidad del conflicto, que debe ser alta, en cuanto que el funcionario tiene que tener una intervención sustancial en la fase de decisión del asunto. Véase infra 5 su concreta propuesta de regulación; y véase infra $9.3 \mathrm{mi}$ opinión acerca de la intensidad del conflicto. También García EsPaÑA, E.: "Negociaciones y actividades prohibidas a los funcionarios públicos. (Los artículos 439 y 441 del Código Penal de 1995", en Jueces para la Democracia $\mathrm{n}^{\circ} 48$ (2003), p. 55-56, viene a establecer de modo restringido el conflicto de intereses, dada la configuración que propone del ilícito penal en este ámbito. Véase su propuesta infra 9.4. 
te la posibilidad de que se utilice la información privilegiada conseguida a través de un empleo público, incluidos los contactos personales y profesionales, que se ponga al servicio de la industria o de una empresa concreta de cara a negociaciones políticas, contrataciones públicas y otras relaciones con las entidades del sector público ${ }^{21}$. En el peor de los casos, puede suceder que ministros u otros altos cargos otorguen ventajas a un sector, industria o empresa concreta, pensando en obtener contratos o empleos lucrativos después de abandonar la Administración pública. Es perfectamente imaginable que funcionarios públicos negocien futuros empleos en el sector privado mientras aún se encuentran ejerciendo un cargo público. Por eso, también se ha previsto en el art. 15 Ley 3/2015 limitaciones al ejercicio de actividades privadas durante los dos años posteriores al cese; o también el art. 60.1 Ley de Contratos del Sector Público (RDLegislativo 3/2011, de 14 de noviembre) prevé que la persona que haya contratado a un alto cargo sin cumplir con estas limitaciones no podrá contratar con las Administraciones públicas durante dicho período. Sin embargo, como se verá luego (infra 5), este tipo de conflicto de intereses quedan fuera del ámbito de tipicidad del art. $441 \mathrm{CP}$ por la sencilla razón de que ya no se reúne la cualidad para ser sujeto activo del mismo.

\section{El régimen de incompatibilidades como garantía de la imparcialidad}

Para evitar esa mezcolanza entre funciones públicas y actividades privadas, con el riesgo que ello comporta para los intereses generales y que la función pública se acabe desviando hacia intereses particulares, la propia Constitución establece en

21 Nieto Martín, Eurodelitos de corrupción y fraude..., cit., p. 111, afirma que "el pantouflage además de afectar a la función pública implica también una distorsión de la competencia", ya que "resulta criticable que determinadas empresas privadas puedan aprovecharse en exclusiva de los conocimientos, informaciones y contactos que poseen gracias al desempeño de un oficio público". 
el art. 103.3, que «la ley regulará... el sistema de incompatibilidades y las garantías para la imparcialidad en el ejercicio de sus funciones» $\rangle^{22}$.

Este sistema de incompatibilidades está integrado fundamentalmente por tres grupos de normas. Con carácter general para todos los empleados públicos de las Administraciones Públicas, se ha aprobado la Ley 53/1984, de 26 de diciembre, de Incompatibilidades del Personal al Servicio de las Administraciones Públicas ${ }^{23}$; y su Reglamento de desarrollo, aprobado por RD 598/1985, de 30 de abril.

Específicamente para los Altos Cargos del Gobierno del Estado se ha aprobado la Ley $\mathbf{3 / 2 0 1 5}$, de 30 de marzo, reguladora del ejercicio del alto cargo de la Administración General del Estado, que sustituyó a la anterior Ley 5/2006, de 10 de abril,

Y Muñoz Conde, F.: Derecho penal. Parte especial, $21^{\mathrm{a}}$ ed., Valencia, 2017, p. 896, afirma que "esta práctica de «puertas giratorias»... por más que pueda entrar dentro de lo permitido legalmente, no deja de ser sospechosa de un tráfico de influencias que en nada favorece la imagen de imparcialidad que deben tener las personas encargadas de la gestión de los asuntos públicos".

22 Morales Prats/Rodríguez Puerta, en Quintero Olivares (dir.): Comentarios a la Parte Especial del Derecho Penal, 10a ed., Pamplona, 2016, p. 1802 , califican el delito de actividad profesional o de asesoramiento incompatible con la función pública del art. $441 \mathrm{CP}$ como un "adelantamiento de las barreras de la intervención penal destinado a evitar cualquier clase de abuso o interferencia en el ejercicio de funciones públicas". "En este sentido -continúan-, la finalidad perseguida con la incriminación de las conductas tipificada en el artículo $441 \mathrm{CP}$ no difiere de la que corresponde al régimen de incompatibilidades o, incluso, a las figuras jurídico-administrativas de la abstención y la recusación".

23 Dicha Ley tiene carácter básico (art. 149.1.18 CE). En Cataluña, por ejemplo, se ha aprobado la Ley catalana 21/1987, de 26 noviembre, de incompatibilidades del personal al servicio de la Administración de la Generalidad. En ciertos ámbitos se ha aprobado una normativa específica sobre incompatibilidades, como, por ejemplo, para los miembros del Poder Judicial (la LO 1/1985, de 18 de enero), para los Diputados y Senadores, miembros de las corporaciones locales, diputados provinciales, miembros del Parlamento Europeo (los arts. 155 ss., 168 ss., 203, 211 ss. LO 5/1985, de 19 de junio, del Régimen Electoral General); o para el personal militar (el RD 517/1986, de 21 de febrero, de incompatibilidades del personal militar). 
que entre otras cosas creó la Oficina de Conflictos de Intereses y los Registros de Bienes y de Actividades. Para los Altos Cargos de los Gobiernos autonómicos se han aprobado también numerosas leyes ${ }^{24}$ y para el personal directivo en las Corporaciones Locales rige la Ley estatal, según lo previsto en la Disp. Adic. $15^{\mathrm{a}}$ LBRL.

Por último, se encuentra otro conjunto de Leyes que regulan lo que se conoce como transparencia o gobierno abierto. Así, en el ámbito estatal se ha aprobado la Ley 19/2013, de 9 de

24 Así, la Ley andaluza 3/2005, de 8 de abril, de Incompatibilidades de Altos Cargos de la Administración de la Junta de Andalucía y de Declaración de Actividades, bienes, Intereses y Retribuciones de Altos Cargos y otros Cargos Públicos; la Ley aragonesa 2/2009, de 11 de mayo, del Presidente y del Gobierno de Aragón; la Ley asturiana 4/1995, de 6 de abril, de incompatibilidades, actividades y bienes de altos cargos del Principado de Asturias; la Ley balear 2/1996, de 19 de noviembre, de incompatibilidades de los miembros del Gobierno y de los altos cargos de la comunidad autónoma de las Islas Baleares; la Ley canaria 3/1997, de 8 de mayo, de Incompatibilidades de los Miembros del Gobierno y Altos Cargos de la Administración Pública de la Comunidad Autónoma de Canarias; la Ley cántabra 1/2008, de 2 de julio, reguladora de los conflictos de intereses de los Miembros del Gobierno y de los Altos Cargos de la Administración de Cantabria; la Ley catalana 13/2005, de 27 de diciembre, del régimen de incompatibilidades de los altos cargos al servicio de la Generalidad; la Ley extremeña $1 / 2014$, de 18 de febrero, de regulación del estatuto de los cargos públicos del Gobierno y la Administración de la Comunidad Autónoma de Extremadura; la Ley gallega $1 / 2016$, de 18 de enero, de transparencia y buen gobierno; la Ley leonesa 3/2016, de 30 de noviembre, del Estatuto de los Altos Cargos de la Administración de la Comunidad de Castilla y León; la Ley madrileña 14/1995, de 21 de abril, de Incompatibilidades de Altos Cargos de la Comunidad de Madrid; la Ley manchega 11/2003, de 25 de septiembre, del Gobierno y del Consejo Consultivo de Castilla-La Mancha; la Ley murciana 5/1994, de 1 de agosto, del Estatuto Regional de la Actividad Política; la Ley foral navarra 19/1996, de 4 de noviembre, de incompatibilidades de los miembros del Gobierno de Navarra y de los altos cargos de la Administración de la Comunidad Foral de Navarra; la Ley riojana 8/2003, de 28 de octubre, del Gobierno e Incompatibilidades de sus miembros; la Ley valenciana 8/2016, de 28 de octubre, de Incompatibilidades y Conflictos de Intereses de Personas con Cargos Públicos no Electos; la Ley vasca 1/2014, de 26 de junio, Reguladora del Código de conducta y de los Conflictos de Intereses de los Cargos Públicos. 
diciembre, de transparencia, acceso a la información pública y buen gobierno. La mayor parte de las Comunidades Autónomas también han aprobado leyes similares en esta materia ${ }^{25}$.

En toda esta normativa se ha establecido un conjunto de obligaciones para los funcionarios que obedecen a tres tipos de razones.

En primer lugar, hay una serie de normas que tratan de garantizar el rendimiento y la atención en el desempeño del cargo: «el estricto cumplimiento de sus deberes», dice la Exposición de Motivos de la Ley 53/198426.

En segundo lugar, y como se dice también en la EM de la Ley 53/1984, existen normas que tratan de garantizar que el ejercicio de actividades privadas no «comprometan [la] imparcialidad e independencia» de los empleados públicos ${ }^{27}$.

Y por último, dentro de ese conjunto de normas que he mencionado hay otras que tratan de garantizar la transparencia.

25 Así, la Ley andaluza 1/2014, de 24 de junio, de Transparencia Pública de Andalucía; la Ley aragonesa 8/2015, de 25 de marzo, de Transparencia de la Actividad Pública y Participación Ciudadana de Aragón; la Ley balear 4/2011, de 31 de marzo, de buena administración y del buen gobierno de las Illes Balears; la Ley canaria 12/2014, de 26 de diciembre, de transparencia y de acceso a la información pública; la Ley catalana 19/2014, de 29 de diciembre, de transparencia, acceso a la información pública y buen gobierno; la Ley extremeña 4/2013, de 21 de mayo, de Gobierno Abierto de Extremadura; la citada Ley gallega $1 / 2016$, de 18 de enero; la Ley leonesa 3/2015, de 4 de marzo, de Transparencia y Participación Ciudadana de Castilla y León; la Ley manchega 4/2016, de 15 de diciembre, de Transparencia y Buen Gobierno de Castilla-La Mancha; la Ley murciana, de 16 de diciembre, de Transparencia y Participación Ciudadana de la Comunidad Autónoma de la Región de Murcia; la Ley foral Navarra 11/2012, de 21 de junio, de la Transparencia y del Gobierno Abierto; la Ley riojana 3/2014, de 11 de septiembre, de Transparencia y Buen Gobierno de La Rioja; la Ley valenciana 2/2015, de 2 de abril, de Transparencia, Buen Gobierno y Participación Ciudadana de la Comunidad Valenciana.

26 También se referirían a ello los aparts. 8 y 10 del art. 53 EBEP. Normas de este tipo serían, por ejemplo, los arts. 10 y 11 apart. 2 y 7 RD 598/1985.

27 Esto mismo prevén también los aparts. 2 y 5 del art. 53 EBEP. Normas de este tipo serían, por ejemplo, el art. 11 aparts. 3 y 5 RD 598/1985. 
La razón última de la existencia de ciertas obligaciones de registro y de publicidad para los funcionarios públicos sería, según expresa la EM de la Ley 19/2013, «permiti[r] una mejor fiscalización de la actividad pública, [contribuir] a la necesaria regeneración democrática, [promover] la eficiencia y eficacia del Estado y [favorecer] el crecimiento económico». Pero una cosa es esa ratio legis y otra lo que se trata de proteger con estas obligaciones, que es sencillamente la transparencia de los empleados públicos ${ }^{28}$.

En resumen, todo este conjunto normativo pretende garantizar la eficacia, la imparcialidad y la transparencia de los empleados públicos. Sin embargo, cabe plantearse, si estos bienes jurídicos pueden justificar la intervención penal frente a ataques a los mismos.

\section{Bien jurídico protegido y justificación de la intervención penal}

Es prácticamente admitido por todos que la intervención penal sólo está justificada cuando se trate de proteger bienes jurídicos, pero se aclara que siempre que ese bien jurídico sea merecedor, necesitado y capaz de protección.

1. En primer lugar, el bien jurídico tendrá que ser merecedor de la protección penal. Para poder castigar una conducta se exige un concreto daño o peligro al prójimo o a la sociedad. De los distintos bienes jurídicos que podemos ver detrás de esas normas sobre incompatibilidades o conflictos de intereses sólo la afectación a la imparcialidad/objetividad merece sanción penal ${ }^{29}$. El titular de

28 Así figura entre los principios y reglas que conforman el Código de Conducta de los empleados públicos (art. 52 EBEP) y que además informan la interpretación y aplicación del régimen disciplinario de los empleados públicos. Asimismo, también se incluye entre los Principios de buen gobierno que obligan a los altos cargos del Estado (art. 26 Ley 19/2013).

29 Se puede considerar que es la opinión mayoritaria entre la doctrina. Así, entre otros, Ganzenmüller Roig/Escudero Moratalla/Frigola Vallina 
este bien jurídico es la sociedad en su conjunto ${ }^{30}$, que se convierte así en el sujeto pasivo del art. $441 \mathrm{CP}$. Si hubiese algún particular menoscabado en sus intereses, éste sería perjudicado, pero no sujeto

(dirs.): Delitos contra la Administración Pública, contra la Administración de Justicia y contra la Constitución, Barcelona, 1998, p. 126; GARCÉs CARBONell, Foro FICP n ${ }^{\circ}$ 2013-2, p. 305; MiR Puig, C.: Los delitos contra la Administración pública en el nuevo Código Penal, Barcelona, 2000, p. 365; Mir Puig, S.: $C D J$ no 30 (1996), p. 324; Morales Prats/Rodríguez Puerta, en G. Quintero Olivares (dir.), Comentarios ..., cit., p. 1800; MuÑoz Conde, Parte Especial, 21 ${ }^{\mathrm{a}}$ ed., cit., p. 894; MuÑoz Cuesta, F.J.: "Inspector de Trabajo y Seguridad Social que comete el delito de negociaciones prohibidas al asesora a empresa privada", en Repertorio de Jurisprudencia Aranzadi no 19 (2008); Orts Berenguer, E.: en T.S. Vives Antón (dir.), Comentarios al Código Penal de 1995, vol. II, Valencia, 1996, p. 1869; IDEM, en J.L. González Cussac (coord.): Derecho penal. Parte especial, $5^{\text {a }}$ ed., Valencia, 2016, p. 674; Polaino Navarrete, M.: Lecciones de Derecho penal. Parte especial, t. II, Madrid, 2011, p. 361, a la imparcialidad anuda también la "incorruptibilidad económica de los funcionarios".

Véase también, entre otras, las SSTS 484/2008, de 11 de julio y 673/2016, de 21 de julio, que consideran que "el bien jurídico protegido lo constituye el correcto funcionamiento de la función pública, conforme a las exigencias constitucionales (v. arts. 9.1 y $103 \mathrm{CE}$ ), con respeto de los principios de objetividad, imparcialidad, igualdad e incorruptibilidad" [en el mismo sentido la SAP Baleares (Secc. 2a) 394/2010, de 1 de diciembre (caso Andratx I) y Baleares (Secc. 2a ) 317/2014, de 17 de noviembre (caso Andratx II)]; las SSTS 19/2010, de 25 de enero y 362/2014, de 25 de abril, según las cuales "el tipo penal protege el deber de imparcialidad del funcionario público cuando la misma es puesta en peligro por una actividad vulneradora no sólo de la legislación específica de compatibilidades de la función pública..., sino cuando esa situación de incompatibilidad se vertebra sobre los propios asuntos que son competencia del funcionario público" [también las SSAP Barcelona (Secc. 21 a) 718/2011, de 23 de mayo; Cáceres (Secc. 1ª) 26/2011, de 14 de febrero].

30 Dice Mir Puig, NEJ t. XVII (1982), p. 204, que "el sujeto pasivo del delito de negociaciones prohibidas a los funcionarios lo es tanto la Administración pública como, mediatamente, la sociedad, pues ya se vio supra que no sólo resulta afectado por el delito de organización interna de la Administración, sino sobre todo el interés que la colectividad tiene en la imparcialidad de la Administración. En este sentido, la sociedad no aparece aquí únicamente por razón del interés genérico que siempre tiene de que no se cometa ningún delito, incluso los que agreden bienes individuales, sino como sujeto del interés objeto de específica tutela por el artículo 404 [CP/1944]”. Lo mismo se puede decir actualmente del art. $441 \mathrm{CP}$. 
pasivo $^{31}$. Los demás bienes deben protegerse, por supuesto, pero no alcanzan la suficiente ofensividad o lesividad como para merecer la respuesta penal. Así, la transparencia si se concibe como un bien a proteger $^{32}$, creo que es puro simbolismo. Tiene que ver sobre todo con aparentar honradez ${ }^{33}$, con eso que se repite tantas veces de que la mujer de César no sólo debe ser honesta, sino también parecerlo. O dicho con otros términos, tendría que ver con el prestigio de la Administración pública ${ }^{34}$ o con la confianza de los ciudadanos en

31 García España, $J p D$ n $^{\circ} 48$ (2003), p. 55.

32 Así lo considera, por ejemplo, Serrano Gómez, A.: Derecho penal. Parte especial, 4a ed., Ed. Dykinson, Madrid, 1999, p. 767, para quien "el bien jurídico protegido es la transparencia de la actuación de los funcionarios dentro de la Administración pública".

También la STS 1497/2002, de 23 de septiembre, señala que "este delito... no requiere que el autor haya producido un daño diverso del jurídico, que consiste en la infracción del deber de abstención, toda vez que se trata de un tipo penal que protege la transparencia del ejercicio de la función y la imagen de la administración" [en igual sentido el AAP Ciudad Real (Secc. $1^{\text {a) }}$ 94/2008, de 5 de junio]. También la SAP Toledo (Secc. $1^{\text {aa }}$ 22/2008, de 10 de abril.

33 Alegre Ávila, J.M.: "Incompatibilidades en el ejercicio de la función (art. 441 CP)”, en F.J. Álvarez García (dir.): Tratado de Derecho penal. Parte especial, t. III («Delitos contra las Administraciones Pública y de Justicia»), Valencia, 2015, p. 607, afirma que "es la apariencia de imparcialidad en el servidor público (trasunto de la objetividad con la que ha de actuar la Administración) el bien jurídico a cuya salvaguarda se contrae el artículo $441 \mathrm{CP}$ 1995, que, en consecuencia, deviene lesionado"; Crespo Barquero, P.: en I. Serrano Butragueño (coord.): Código penal de 1995. (Comentarios y jurisprudencia), t. II, Granada, 2002, p. 2440, dice que se trata de un "tipo de peligro, que sólo potencialmente alcanza a erosionar el bien jurídico común a los delitos contra la Administración Pública [que sería la imparcialidad y la eficacia prestacional]", por lo que este delito sólo menoscaba "la imagen o la apariencia de imparcialidad". Más adelante insiste en ello y señala que el peligro para el bien jurídico protegido no es porque "el funcionario traicione su deber de fidelidad 'sirviendo a otro señor' -noción bajo la que subyace cierto tiente totalitario del concepto de Administración- sino porque se arriesga la apariencia de imparcialidad de la gestión administrativa" (p. 2442).

34 Quizás por este motivo entran dentro del ámbito de enjuiciamiento del Tribunal del Jurado muchos delitos de funcionarios. Sin embargo, hay que llamar la atención que, con buen criterio, dada la complejidad de este delito, 
el correcto desempeño de la función pública ${ }^{35}$. Sin embargo, estos intereses no pueden ser objeto de protección penal. Lo importante para el Derecho penal no debe ser eso, sino si se afecta al correcto desempeño de las funciones públicas ${ }^{36}$. La transparencia más que un bien jurídico es una medida de prevención situacional de posibles conflictos de intereses. Su propósito es sencillamente incrementar la percepción del riesgo de detección de aquellos que no cumplen con el deber de abstención en caso de conflicto de intereses, así como de los sentimientos de vergüenza o de culpabilidad en el infractor.

Tampoco la eficiencia o rendimiento tiene la suficiente entidad como para ser objeto de protección penal ${ }^{37}$. Lo que hay

el art. 1.2 letra j) LOTJ no incluye dentro de dicha competencia el conocimiento y fallo de las causas por delito del art. $441 \mathrm{CP}$. Eso no impide, sin embargo, que acaben conociéndolos: por ejemplo, la STS 765/2014, de 4 de noviembre; o la SAP Zaragoza (Secc. $6^{\mathrm{a}}$ ) 1/2014, de 14 de abril [confirmada en cuanto a la condena por el art. 441 CP por la STSJ Aragón (Sala Civil y Penal) 4/2014, de 16 de septiembre].

35 Véase, por ejemplo, Garcés CARbonell, Foro FICP n ${ }^{\circ} 2013-2$, p. 302, quien afirma que "la noción objetividad, se hace sinónima de la de transparencia, el tipo penal que protege la transparencia del ejercicio de la función pública y la imagen de la administración y su prestigio e, incluso, de la de pureza de la función pública o dignidad en el desempeño de los cometidos público y, sobre todo, de la de imparcialidad" (sic).

36 En Alemania hay autores sostienen esta perspectiva (por todos, WAGNER, H.: Amtsverbrechen, Berlín, 1975, pp. 50 ss.), que yo calificaría de simbólica, en el sentido de tratar de garantizar la confianza de la generalidad en el recto funcionamiento de la función pública. En este sentido WAGNER cita a Cramer, Dreher, Jescheck, Maurach, Rudolphi, Schröder, entre otros.

Sin embargo, considero acertadas las críticas vertidas a esta opinión por Octavio de Toledo y Ubieto, al entender que se podría decir que es la propia infracción de los deberes del cargo lo que conlleva la pérdida de la confianza pública en el correcto ejercicio de las funciones públicas, por lo que no sería necesario hacer referencia además a dicha confianza. Bastaría con la simple violación de esos deberes, sin necesidad de hacer mención a esa confianza. Pero es que además, incluso interpretándose el bien jurídico en este sentido simbólico, más correcto sería entender que se refiere a la corrección en el ejercicio de dichas funciones, y no a la confianza pública en esa corrección, dado que sólo protegiendo aquélla se consigue ésta (La prevaricación de funcionario público, Madrid, 1980, p. 268).

37 En cambio, Rodríguez López, P./Sobrino Martínez, A.I.: Delitos contra la Administración Pública. Delincuencia Administrativa. Cuando el represen- 
detrás de esas normas sobre incompatibilidades es una cuestión interna de la Administración. Trata de garantizar que los funcionarios trabajen bien, nada más. Tiene que ver sencillamente con un incumplimiento contractual, que se puede resolver mediante una respuesta disciplinaria ${ }^{38}$. Si esos intereses se elevan a la categoría de bien jurídico protegido penalmente, se estaría incurriendo en una mera configuración ad intra de los deberes del cargo, que desde mi modesto punto de vista, y también del de otros afamados penalistas, no tiene cabida en la CE/1978.

2. En segundo lugar, la intervención penal tiene que ser necesaria para proteger la imparcialidad/objetividad, es decir, no tienen que ser suficientes otros mecanismos, en particular el Derecho administrativo sancionador, para garantizarla. A mi

tante de la Administración participa en el delito, Barcelona, 2008, p. 387, entienden que el bien jurídico protegido es "la imparcialidad y eficacia de la Administración". También aluden, aunque no se comprende muy bien, a que "el art. 441 protege el patrimonio público de la duplicidad de posiciones del funcionario". Esta última expresión también aparece en la SAP Salamanca (Secc. $1^{a}$ ) 3/2006, de 24 de enero.

38 El incumplimiento de las normas sobre incompatibilidades se considera falta muy grave, de acuerdo con lo dispuesto en el artículo 95.2.n) EBEP. El art. 25.1 a) Ley $3 / 2015$ también considera falta muy grave que los altos cargos incumplan las normas de incompatibilidades a que se refiere dicha ley. Si se trata simplemente de un incumplimiento de los plazos u otras disposiciones de procedimiento en materia de incompatibilidades la falta se considerará grave, siempre que no suponga mantenimiento de una situación de incompatibilidad, según lo establecido en el artículo 7.1 k) del Reglamento de Régimen Disciplinario de los Funcionarios de la Administración del Estado, aprobado por Real Decreto 33/1986, de 10 de enero. El art. 96 EBEP no establece exactamente qué sanción corresponde a estas infracciones, sólo dice que la separación del servicio o el despido disciplinario del personal laboral sólo podrá sancionar la comisión de faltas muy graves. El art. 26.2 Ley 3/2015 es más preciso y dice que la sanción por infracción muy grave comprenderá: a) La destitución en los cargos públicos que ocupen, salvo que ya hubieran cesado en los mismos. b) La pérdida del derecho a percibir la compensación tras el cese... c) La obligación de restituir, en su caso, las cantidades percibidas indebidamente en relación a la compensación tras el cese. Además, el art. 26.4 Ley 3/2015 establece que no podrán ser nombrados para ocupar un alto cargo durante un periodo de entre 5 y 10 años. 
modo de ver, la necesidad de la intervención penal resulta más que evidente si tenemos en cuenta los niveles de corrupción que se han alcanzado en los últimos tiempos. Pero lo que resulta más sangrante aun es que los mecanismos administrativos que se han implantado para tratar de evitar conflictos de intereses están fallando. Y es que "la regulación vigente está más orientada al cumplimiento formal de [1]os deberes [de información] que al aseguramiento de la calidad de la información facilitada" 39 . Nunca se ha cuestionado verdaderamente la actividad profesional o de asesoramiento de los altos cargos en empresas privadas, no ya después del período de espera de dos años que contempla la Ley, sino incluso dentro de dicho período, lo cual, claramente, compromete la objetividad de la Administración. En una década de funcionamiento de la Oficina de Conflictos de Intereses solamente ha dictado dos resoluciones de incompatibilidad para ex altos cargos del Gobierno que querían incorporarse al sector privado durante los dos años siguientes a su cese ${ }^{40}$. Por tanto, apenas el 0,5\% (2 de 363) de las solicitudes referidas a altos cargos que querían realizar "actividades privadas" tras su cese fueron rechazadas.

El propio Tribunal de Cuentas ha publicado el año pasado un Informe de fiscalización del cumplimiento de la normativa en

39 Cerrillo i Martínez, Eunomía no 12 (2017), p. 88. Este autor trae a colación un informe de 2016 de la Oficina Antifraude de Cataluña, en el cual se dice que "las instituciones y sus representantes perciben las herramientas de gestión de los conflictos de interés como meras obligaciones formales que se deben cumplir en vez de verdaderos instrumentos para asegurar la imparcialidad y la objetividad de sus servidores públicos".

40 Uno fue el caso de Lourdes Arana, ex directora general de la Fundación Española para la Ciencia y la Tecnología (FECYT), que recibió la negativa para incorporarse como directora en la Universidad privada de Deusto, porque había concedido unos proyectos de investigación. El otro fue el caso de Alfonso Martinell, que fue director general de Relaciones Culturales y Científicas de la Agencia de Cooperación Española (AECID), a quien se le denegó autorización para firmar un contrato de servicios profesionales con la Fundación Carolina, en parte pública y los ex altos cargos no pueden celebrar contratos de asistencia técnica o de servicios con las AAPP durante los dos años siguientes a su cese. 
materia de indemnizaciones recibidas por cese de altos cargos y del régimen retributivo de altos directivos de determinadas entidades del sector público estatal, ejercicios 2012-2014 (Informe $\mathrm{n}^{\mathrm{o}} 1.152$, de 27 de abril de 2016), en el cual se critica con suma dureza la labor de la Oficina de Conflictos de Intereses de los Altos Cargos, ya que viene a decir que la Oficina no investiga y que da por buenos los datos que presentan los Altos Cargos $^{41}$.

A nivel autonómico y a nivel municipal, se podría decir lo mismo. Y esta situación no es de ahora, sino que ya viene de hace mucho tiempo. Así, por ejemplo, Carlos Mir Puig decía que se tiene que recurrir a "la fuerza preventiva que caracteriza a la sanción penal, atendidos los numerosos casos de infracción de la normativa de incompatibilidades por parte de los funcionarios públicos, en que la sanción administrativa acaso ha devenido ineficaz" ${ }^{\prime 2}$. Y por aquella época también PALOMO DEL ARCO se quejaba, que la laguna de punibilidad que provocaba la redacción que entonces tenía el art. $439 \mathrm{CP}$, cobraba mayor riesgo cuando desde el ámbito administrativo las sanciones eran "de carácter muy liviano", con un "régimen muy difuso", y que "a nivel de responsabilidad de políticos de la Administración local, la per-

41 Por ejemplo, en la p. 112 del Informe, la conclusión 4 dice así: "La OCI se limitó a recibir las declaraciones y gestionar los registros sin utilizar la posibilidad legal de servirse de la colaboración de las administraciones tributarias y de la seguridad social para realizar actuaciones de verificación de los datos declarados. Tampoco se utilizó la posibilidad legal de servirse de la colaboración de las administraciones tributarias y de la seguridad social para detectar posibles omisiones en las declaraciones de bienes o actividades de los altos cargos de las entidades fiscalizadas. No existen criterios para determinar de qué modo debe servirse la OCI de la colaboración de la Agencia Tributaria y las Entidades de la Seguridad Social; ni procedimientos para realizar comprobaciones periódicas y aleatorias de las actividades y bienes de los altos cargos. Durante el periodo fiscalizado, únicamente se solicitaron aclaraciones sobre datos o actividades previamente declaradas por los propios altos cargos o sobre noticias aparecidas en prensa. No se realizó comprobación alguna sobre los bienes y actividades de los altos cargos de las entidades fiscalizadas que no declararon actividades ni aparecieron en prensa".

42 Mir PUIG, Los delitos contra la Administración pública ..., cit., p. 365. 
misividad es mayor; de forma que la actual legislación penal y me temo que también la administrativa, bendice que un alcalde o un concejal con competencias en urbanismo puedan desarrollar una actividad económica privada de promoción inmobiliaria en el mismo municipio donde ostenta el cargo"43.

Por tanto, cabe concluir que la intervención penal en este terreno resulta necesaria dada la escasa eficacia del sistema administrativo sancionador.

3. Por último, el Derecho penal también tiene que ser capaz de proteger la imparcialidad, descubriendo y persiguiendo eficazmente conductas que atenten contra la misma. Como acabo de señalar, la Oficina de Conflictos de Intereses de los Altos Cargos deja mucho que desear, pero no porque no pueda, sino porque no hay voluntad. Hay que dotarla de más recursos, y que sea auténticamente independiente. Lo mismo hay que decir de todos los organismos autonómicos que se han creado con el mismo propósito y de las funciones de control que les corresponden a los Secretarios de los ayuntamientos en esta materia. En el ámbito penal, a la Fiscalía Anticorrupción y a las brigadas de la Policía especializadas en delincuencia económica, y por supuesto, a la propia Judicatura, se les tiene que facilitar más recursos $^{44}$. Según los datos de las Memorias de la Fiscalía General del Estado el número de diligencias previas por delitos contra la Administración pública casi se ha triplicado en ocho años: de 1.519 en 2007 a 5.398 en 2015; y si nos fijamos en el número de condenados (según datos del INE), en 2015 ha sido 20 veces mayor que hace una década (77 condenados en 2006 frente a 1.591 en 2015).

43 Palomo del Arco, A.: "Negociaciones prohibidas a los funcionarios públicos en el Código Penal de 1995: ¿legalización de la contratación en interés propio?", en J.C. Ferré Olivé (dir.): Delitos financieros, fraude y corrupción en Europa, vol. 3 («Fraude y corrupción en la Administración Pública»), Salamanca, 2002, p. 253.

44 Según datos de la Memoria de la Fiscalía General del Estado de 2016, a 31 de diciembre de 2015 la plantilla de la Fiscalía Anticorrupción estaba integrada por 133 personas, entre fiscales, unidades de apoyo de la Agencia 
Por tanto, también cabe afirmar que el Derecho penal es capaz de castigar delitos de funcionarios que afecten a la imparcialidad.

En atención a todo lo expuesto, se puede concluir que la intervención penal en esta materia está justificada.

\section{Sujeto activo}

El sujeto activo del delito del art. $441 \mathrm{CP}$ es la «autoridad o funcionario público», lo cual debe interpretarse conforme establece el art. $24 \mathrm{CP}^{45}$.

El administrativista Juan Manuel Alegre Ávila, siguiendo una interpretación de estos términos demasiado formal, basándose en una delimitación del concepto de «participación en funciones públicas» del art. $24 \mathrm{CP}$ en atención al sometimiento de la entidad a un régimen de Derecho público o de Derecho privado, excluye las asociaciones, sociedades y fundaciones públicas, entre otros entes, de la noción de Administración Pública, y por ende, excluye del ámbito de este tipo, haciéndolo extensi-

Tributaria, de la Intervención General del Estado, de la Policía Nacional y de la Guardia Civil.

Gimeno Sendra, V.: "Corrupción y propuestas de reforma", en Diario La Ley $\mathrm{n}^{\circ} 7990$ (26 diciembre 2012), empieza por pedir que se dote de mayores medios a la Justicia y pone un dato significativo: mientras que el número de jueces y magistrados en España es de 5.300, lo que da una ratio de 1 juez por cada 100.000 habitantes, en cambio, hay 103 políticos por cada 100.000 habitantes.

45 Véanse, por todos, JAVATO MARTín, A.: "El concepto de funcionario y autoridad a efectos penales", en Revista Jurídica de Castilla y León n $\mathrm{n}^{\circ} 23$ (2011), p. 145 ss.; Martín Lorenzo, M.: "Concepto penal de funcionario y externalización de funciones públicas", en Derecho Penal para un Estado social y democrático de Derecho. Estudios penales en homenaje al profesor Emilio Octavio de Toledo y Ubieto, Madrid, 2016, p. 209 ss.; RAmón RiBas, E.: "La derogación jurisprudencial del artículo 24.2 CP (concepto de funcionario público)", en Estudios Penales y Criminológicos no 34 (2014), p. 173 ss.; Roca de Agapito, L.: "Concepto de autoridad y de funcionario público a efectos penales", en Revista de Derecho y Proceso Penal n 31 (2013), p. $151 \mathrm{ss}$. 
vo también a los demás delitos de funcionarios, al personal de las personas jurídicas públicas que utilizan una forma privada ${ }^{46}$. Además, también desde una visión estrictamente administrativa, hace una equiparación entre «autoridades» y titulares de órganos stricto sensu de la Administración, por un lado, y por otro, entre «funcionarios»e integrantes de las unidades administrativas ${ }^{47}$.

Esta delimitación del sujeto activo del art. $441 \mathrm{CP}$ no se puede compartir, de ninguna manera. Para empezar, el concepto de autoridad o funcionario público no se puede limitar exclusivamente al personal de la Administración pública en sentido estricto, sino que a efectos penales por funcionario público hay que entender aquel que participa en funciones públicas, y éstas comprenden todas las actividades del Estado, no sólo el administrar, sino también el legislar y el juzgar ${ }^{48}$. Por tanto, el sujeto activo del art. $441 \mathrm{CP}$ debe comprender igualmente a miembros electos de las Asambleas Legislativas y de las Corporaciones Locales, así como a los del Poder Judicial, y no sólo al personal de la Administración. En este sentido, cabe destacar cómo MuÑOZ CONDE pone de ejemplo de este delito precisamente el caso de "juez que asesora a un bufete privado en asuntos en los que él debe intervenir como tal juez" ${ }^{\prime 4}$. En la jurisprudencia también

46 Alegre Ávila, Tratado..., cit., p. 615. Tampoco los incluye Garcés CarboNELL, Foro FICP n ${ }^{\circ} 2013-2$, p. 305.

47 Alegre Ávila, Tratado..., cit., p. 616 y 627.

48 Como dice Delgado Gil, Delitos cometidos por funcionarios públicos..., cit., p. 60 n. 70, los principios de objetividad, imparcialidad e igualdad no sólo constituyen la base de toda actividad administrativa, sino "de la actuación de todos los poderes públicos". "En este sentido -continúa-, puesto que el bien jurídico común a todos los delitos del Tít. XIX es el correcto ejercicio de las actividades públicas..., parece preferible apuntar que los principios constitucionales de objetividad, imparcialidad e igualdad son la base de la actuación de todos los poderes públicos, todos ellos sujetos en su actuación... a los citados principios". Asimismo, también Delgado GIL, A.: "El necesario ánimo de obtener un beneficio económico y el «asesoramiento» en el delito de actividades incompatibles a los funcionarios públicos. (A propósito de la STS 25 de enero de 2010)", en La Ley penal n 75 (2010), p. 74, precisamente comentando un caso relativo a un Magistrado.

49 Muñoz Conde, Parte Especial, cit., p. 895. 
se encuentran ejemplos de este tipo, como las SSTS 19/2010, de 25 de enero (caso del Presidente de la AP de Las Palmas); 362/2014, de 25 de abril (caso ITV Cataluña); o el ATS de 2 de junio de 2008 (Presidenta del TC). Asimismo, el art. 1.1 Ley 53/1984 es claro al respecto.

En cuanto al personal que trabaja para entes públicos que utilizan una forma privada existen argumentos legales y político-criminales como para incluir, al menos, al personal directivo de dichos entes dentro del ámbito del sujeto activo de este delito. En este sentido, el propio Alegre Ávila reconoce que su interpretación va en contra del art. 2.2 de la Ley 39/2015, de 1 de octubre, del Procedimiento Administrativo Común de las Administraciones Públicas. Aun más claro es el art. 2 de la Ley 47/2003, de 26 de noviembre, General Presupuestaria, en relación con el sector público estatal; o el art. 2 de la LO 2/2012, de 27 de abril, de Estabilidad Presupuestaria y Sostenibilidad Financiera ${ }^{50}$. Pero es que el propio ámbito de aplicación del sistema de incompatibilidades, lo cual resulta determinante para la interpretación del art. $441 \mathrm{CP}$, es taxativo al respecto, incluyendo, con ciertos requisitos, los entes públicos con forma jurídica privada (arts. 1.1 y 2 Ley 53/1984).

Desde un punto de vista político-criminal, además, no es admisible que so pretexto de flexibilizar la actividad de la Administración se pretenda una acción deliberada de huida del Derecho público (no ya del administrativo, sino también del

50 Véase también el Reglamento de desarrollo de la Ley 18/2001, General de Estabilidad Presupuestaria, en su aplicación a las Entidades Locales (aprobado por RD 1463/2007, de 2 de noviembre), que crea el «Inventario de Entes del Sector Público Local». El art. 2, relativo al alcance subjetivo del Inventario, maneja un concepto amplio de Administración. A raíz de los Acuerdos tomados en el Consejo de Política Fiscal y Financiera de las Comunidades Autónomas (publicados por la Orden HAC/2283/2003, de 31 de julio) se decide crear el «Inventario de Entes Dependientes de las Comunidades Autónomas». Y finalmente, también existe un «Inventario del Sector Público Estatal». Inventarios todos ellos disponibles en www.minhafp.gob. es (en "Central de información"). 
penal $)^{51}$. Ciertamente, esta utilización de personas jurídicas instrumentales de régimen jurídico privado puede estar justificada cuando la Administración pretende actuar en el tráfico mercantil como un empresario más (si bien con límites, pues la normativa de la UE prohíbe cualquier ventaja a las empresas públicas que distorsione la competencia); sin embargo, carece de toda justificación en otro caso y ni el legislador, ni aun menos la Administración motu propio, pueden dispensar a una organización inequívocamente pública (por su origen, por su actuación, dominada totalmente por la matriz pública, por su financiación, también de procedencia pública) de las vinculaciones que la Constitución y las Leyes le imponen (legalidad, interdicción de la arbitrariedad, control judicial, control presupuestario, régimen patrimonial y de contratación, régimen retributivo del personal, y por supuesto, también el régimen de incompatibilidades, entre otras cosas). Como se suele decir, el régimen jurídico privado no puede convertirse en una "patente de corso" para dichos entes, $\mathrm{y}$ en este terreno de ninguna manera se puede admitir que "el hábito hace al monje".

En los ámbitos civil, mercantil o laboral se conocen técnicas como el levantamiento del velo para tratar de impedir fraudes de este tipo, o en el terreno administrativo la de los actos separables, en virtud de la cual se considera que siempre existirá un núcleo esencialmente público, como expresión del centro subjetivo último de la Administración como organización política, como «poder público» en el sentido en el que lo emplea el art. 9 CE.

En el ámbito penal también contamos con algún instrumento para tratar de poner coto a esta argucia. Precisamente el concepto penal de funcionario, como concepto funcional que es, trata de solventar esa huida del Derecho administrativo, y para que esto no suponga a su vez una huida del Derecho penal para

51 Véase, al respecto, entre otros, González LóPEZ, J.J.: "La 'huida del derecho administrativo' como factor criminógeno", en Revista de Derecho Penal y Criminología $\mathrm{n}^{\mathrm{o}} 16$ (2016), p. 375 ss. 
los administradores y consejeros de los diferentes entes creados por las Administraciones públicas que quedan sometidos a un régimen jurídico privado, resulta necesario acoplar dos criterios barajados por la doctrina penal en la delimitación de las «funciones públicas» propias del concepto de funcionario a efectos penales: uno el subjetivo y otro el material. El subjetivo, en cuanto incardinación del ente al esquema organizativo amplio de la Administración pública. Y el material, representativo de una actividad esencialmente pública, esto es, expresión de la actuación de un «poder público» dirigida al interés general. De este modo, el concepto de «funciones públicas» del art. $24 \mathrm{CP}$ se adecúa mejor a los principios constitucionales que vinculan a los poderes públicos, y por ende, a un concepto funcional de funcionario, en el que lo importante es que ese sujeto tenga la capacidad de afectar al bien jurídico protegido en cada uno de los delitos en que interviene.

A propósito de esta capacidad para afectar al bien jurídico, es preciso tener en cuenta que el funcionario tiene que realizar una actividad profesional o de asesoramiento en asunto en que intervenga «por razón de su cargo» o que sea de los que se tramitan, informan o resuelven en «la oficina o centro directivo en que estuviere destinado o del que dependa». Esto delimita también el alcance del sujeto activo, por cuanto que él o su oficina tiene que tener competencia ${ }^{52}$ sobre el asunto (infra 7 ).

Todo ello convierte al delito de asesoramiento o de actividad profesional incompatible con la función pública del art. $441 \mathrm{CP}$ en un delito especial propio ${ }^{53}$. A este respecto, es importante resaltar que la cualidad especial del sujeto activo tiene

52 Por este motivo, la SAP Lleida (Secc. $1^{\text {a }}$ ) 362/2013, de 23 de noviembre, por ejemplo, no condenó al Presidente de una Entidad Municipal Descentralizada que había concedido, sin competencias para ello, 13 licencias de obras a diferentes compradores de terrenos adquiridos a sociedades mercantiles de las cuales era administrador único.

53 Así, expresamente, Crespo Barquero, en Serrano Butragueño (coord.): Código Penal II, cit., p. 2440; García España, $J p D$ n $^{\circ} 48$ (2003), p. 56; Polaino 
que darse en el mismo momento de la realización de la conducta típica, es decir, para que exista autoría punible el sujeto tiene que ser funcionario cuando realiza el asesoramiento o la actividad profesional. Solamente de este modo se puede decir que se haya visto comprometido el principio de imparcialidad de forma típica. Por este motivo, si el funcionario ya hubiese cesado en su cargo, aunque pueda seguir teniendo una incompatibilidad durante los dos años siguientes, el delito del art. 441 CP no sería aplicable ${ }^{54}$. El incumplimiento del régimen de incompatibilidades en este caso sólo daría lugar a una infracción administrativa. En cambio, en otros países, como Francia, sí se ha previsto ${ }^{55}$.

NAVARRETE, Lecciones II, cit., p. 360. Igualmente las SSTS 484/2008, de 11 de julio; 199/2012, de 15 de marzo; 362/2014, de 25 de abril; 765/2014, de 4 de noviembre; SSAP Baleares (Secc $1^{\text {a }}$ ) 26/2010, de 15 de marzo; Barcelona (Secc. 21 ${ }^{\text {a }}$ ) 718/2011, de 23 de mayo; Cáceres (Secc. 1ª) 26/2011, de 14 de febrero.

Por falta de la cualidad especial de sujeto activo, la SAP Valencia (Secc. $5^{\text {a }}$ ) 138/2005, de 19 de abril, absolvió a un arquitecto técnico que, sin nombramiento ni contrato laboral de ninguna clase, prestaba sus servicios como profesional liberal para un Ayuntamiento, interviniendo a la vez en un proyecto privado de obras y también en el expediente de licencia de actividad del local al cual las obras se referían.

54 Así, expresamente, Córdoba Roda, en J. Córdoba Roda/M. García Arán (dirs.): Comentarios al Código Penal. Parte Especial, t. II, Madrid, 2004, p. 2106; Crespo Barquero, en Serrano Butragueño (coord.): Código Penal II, p. 2440; García España, $J p D$ n $^{\circ} 48$ (2003), p. 56.

Véase, por ejemplo, el AAP Castellón (Secc. 2a) 360/2004, de 29 de diciembre. Asimismo, la SAP Madrid (Secc. $5^{\text {a }}$ ) 43/2006, de 16 de mayo (confirmada por la STS 268/2007, de 9 de abril), que conoció de un posible delito del art. 441 CP cometido por el Director General de Obras Hidráulicas del Ministerio de Medio Ambiente con motivo de las obras de recrecimiento del embalse de Yesa (Zaragoza), adjudicadas a una UTE formada ACS, Ferrovial y FCC, no consideró probado que el acusado hubiese tenido reuniones con ACS durante el ejercicio de su cargo, no obstante, en menos de 4 meses después de su cese, fue contratado por ACS (f.j. $7^{\circ}$ ).

55 Art. 432-13 CP francés (conforme a la ley no 2017-55 de 20 de enero de 2017): «Será castigado con tres años de prisión y multa de 200.000 euros, cuyo monto puede incrementarse al doble del producto de la infracción, el hecho, cometido por la persona que hubiese estado encargada, como miembro del Gobierno, miembro de una autoridad administrativa independiente 
En nuestro país solamente cabría imaginar la posibilidad de una responsabilidad penal del exfuncionario ${ }^{56} \mathrm{si}$ el asesoramiento o la actividad profesional son simulados y en realidad encubren un cohecho pasivo subsiguiente pactado (art. $421 \mathrm{CP}$ ). Otros delitos como el uso de información privilegiada o el descubrimiento y revelación de secretos, también exigen la cualidad de funcionario público.

o de una autoridad pública independiente, como titular de una función ejecutiva local, funcionario público, militar o agente de una administración pública, dentro del marco de las funciones que ha efectivamente ejercido, bien de supervisar o de controlar a una empresa privada, bien de formalizar contratos de toda naturaleza con una empresa privada o de informar sobre tales contratos, bien de proponer directamente a la autoridad competente las decisiones relativas a las operaciones realizadas por una empresa privada o de informar sobre tales decisiones, de tomar o recibir una participación por trabajo, asesoramiento o como aportación de capitales en una de tales empresas, antes de la expiración del plazo de los tres años siguientes a su cese en estas funciones.

Será castigada con las mismas penas toda participación por trabajo, asesoramiento o aportación de capitales, en una empresa privada que posea al menos el $30 \%$ de capital en común o que haya celebrado un contrato que conlleve una exclusividad de hecho o de derecho con una de las empresas mencionadas en el párrafo anterior.

A los efectos de los dos primeros párrafos, se asimilará a una empresa privada toda empresa pública que ejerza su actividad en un sector de la competencia y conforme a las reglas del derecho privado.

Estas disposiciones serán aplicables a los agentes de establecimientos públicos, de las empresas públicas, de las sociedades de economía mixta en las cuales el Estado o los entes públicos detenten directa o indirectamente más del $50 \%$ del capital y de los operadores públicos previstos por la ley $\mathrm{n}^{\circ}$ 90-568 de 2 de julio de 1990 relativa a la organización del servicio público de correos y de France Télécom.

La infracción no se producirá por la sola participación en el capital de sociedades cotizadas en bolsa o cuando los capitales se reciban por transmisión hereditaria».

56 Nieto Martín, en Eurodelitos de corrupción y fraude..., cit., p. 57, ya planteó expresamente su incriminación (véase el apart. 2 del art. 8 de la Propuesta de Eurodelitos de Corrupción). También propone la incriminación de un delito de omisión de las obligaciones legales de declaración de bienes, de abstención o de reconocimiento de compatibilidad, en lo cual no estoy de acuerdo. Tampoco estoy de acuerdo en restringir el ámbito del sujeto activo 


\section{Conductas típicas: realizar una actividad profesional o de asesoramiento}

El núcleo de la conducta típica del art. $441 \mathrm{CP}$ consiste en «realizar [...] una actividad profesional o de asesoramiento permanente o accidental». En realidad se prevén dos conductas que configuran un tipo mixto alternativo (STS 765/2014, de 4 de noviembre).

Se trata de un delito de acción, que sólo admite su comisión activa, pues no se puede «realizar una actividad profesional o de asesoramiento» por omisión ${ }^{57}$. Tampoco cabe la aplicación

a los altos cargos dentro de la Administración. La propuesta de este autor era la siguiente:

Artículo 8. Transparencia patrimonial y conflicto de intereses.

«1. Será sancionado con... quien, como miembro de una asamblea legislativa nacional o regional, europarlamentario, alcalde o concejal de grandes municipios o alto cargo de la Administración pública nacional, regional, local o comunitaria:

a) en un asunto en el que deba intervenir, de forma relevante, por razón de su cargo, omita cumplir con las obligaciones legales de declaración, abstención o autorización cuando tenga un interés económico en el mismo,

b) fuera de los casos admitidos legalmente, realice, por sí solo o por persona interpuesta, una actividad profesional, económica, permanente u ocasional en un asunto concreto con relevancia patrimonial en el que haya de intervenir o haya intervenido por razón de su cargo de forma relevante.

2. Será sancionado con... quien habiendo desempeñado un cargo de los mencionados en el apartado primero, de forma contraria a la ley, entable una relación laboral, de representación legal o de asesoramiento con un particular o empresa privada que guarde relación directa con asuntos de relevancia patrimonial en los que anteriormente haya intervenido de forma relevante por razón de su cargo».

También GonZÁLEZ BARRoso, de Transparencia Internacional, sugiere para hacer frente al fenómeno de las puertas giratorias que "quizás la solución sea la resultante de un conjunto de medidas, entre las que no descartaría el Código Penal, como nuestros amigos franceses, pero también habría que seguir trabajando un aspecto fundamental, cual es el de la profesionalización de la Función Pública Directiva en nuestro país" ["El fenómeno de las puestas giratorias", en Eunomía n ${ }^{\circ} 11$ (2016), p. 317].

57 Así, entre otros, Catalán Sender, J.: "El delito de negociaciones prohibidas a funcionarios en el nuevo Código Penal", en Actualidad Penal n ${ }^{\circ} 29$ (1998), p. 533; García España, $J p D \mathrm{n}^{\circ} 48$ (2003), p. 61. También la STS 119/2012, de 15 de marzo. 
del art. $11 \mathrm{CP}$, puesto que no estamos ante un delito de resultado, sino de mera actividad ${ }^{58}$, que no requiere la producción de un resultado distinto de la realización de la propia conducta profesional o de asesoramiento. De producirse un resultado que afecte concretamente al desempeño de la función pública daría lugar a un concurso de delitos, por ejemplo, con el delito de prevaricación ${ }^{59}$.

Según el Diccionario de la RAE, profesional significa "perteneciente o relativo a la profesión" y la segunda acepción del término profesión significa "empleo, facultad u oficio que alguien ejerce y por el que percibe una retribución" ${ }^{60}$; y asesoramiento es la "acción y efecto de asesorar o asesorarse", siendo

58 Así, entre otros, Catalán Sender, $A P$ n ${ }^{\circ} 29$ (1998), p. 533; Garcés Carbonell, Foro FICP no 2013-2, p. 306; Polaino Navarrete, Lecciones II, cit., p. 360; PIÑol RodRíguez, J.R.: en Suárez-Mira Rodríguez (coord.), Manual de Derecho penal, t. II («Parte Especial»), 5 ed., Madrid, 2008, p. 550. En cambio, Delgado Gil, Delitos cometidos por funcionarios..., cit., p. 213, equipara la realización de la actividad privada con un resultado exigido en el tipo; también en este sentido, Alegre Ávila, Tratado III, p. 635 .

En la jurisprudencia lo califican como delito de mera actividad, entre otras, las SSTS 484/2008, de 11 de julio; 765/2014, de 4 de noviembre; SSAP Baleares (Secc. 1ª) 26/2010, de 15 de marzo; Barcelona (Secc. 21 ${ }^{\text {a }}$ ) 718/2011, de 23 de mayo; Cáceres (Secc. 1ª) 26/2001, de 14 de febrero; Sevilla (Secc. $7^{\text {a) }} 62 / 2003$, de 20 de noviembre.

59 Así, entre otras, SSTS 1048/1997, de 18 de julio; 92/1999, de 1 de febrero; 1497/2002, de 23 de septiembre; 1189/2010, de 30 de diciembre.

60 Así, la SAP Baleares (Secc. 2 $2^{\mathrm{a}}$ ) 317/2014, de 17 de noviembre (caso Andratx II), equipara «actividad profesional» a "cualquier actividad que implique la finalidad de obtener ingresos".

La STS 1497/2002, de 23 de septiembre, afirma que "la actividad profesional mencionada en el texto legal no se refiere a una profesión liberal, como parece haber entendido el Tribunal a quo, sino a una actividad que el autor ejerce para proporcionarse medios con una relativa permanencia".

La STS 1318/2004, de 15 de noviembre, entendió que una participación muy pequeña, del $1 \%$, en el capital de una sociedad, "no constituye, en modo alguno, el ejercicio de «una actividad profesional o de asesoramiento permanente o accidental», que es el verdadero núcleo de esta infracción penal". 
asesorar equivalente a "dar consejo o dictamen" $"$ Ambas conductas pueden ser realizadas, según dispone el propio art. 441 $\mathrm{CP}$, de modo «permanente», es decir, indefinidamente o de una forma continuada en el tiempo ${ }^{62}$, lo cual dará lugar a problemas de unidad o pluralidad de delitos que veremos en su momento (infra 13), pero también se pueden llevar a cabo de modo «accidental», es decir, puntualmente o de una forma provisional. Conforme a ello el art. $441 \mathrm{CP}$ se puede clasificar como delito eventualmente permanente, esto es, unas veces puede ser instantáneo y otras permanente.

El asesoramiento o la actividad profesional debe poner en peligro la imparcialidad administrativa, por lo que habrá que hacer un análisis teleológico-valorativo en función del ámbito de protección de la norma. Aunque formalmente se pueda entender típica una conducta, habrá que valorar si esa conducta es o no adecuada (en términos de previsibilidad objetiva) para poner en peligro el bien jurídico protegido ${ }^{63}$. En este sentido, CóRDOBA RoDA considera necesaria "una interpretación restrictiva que limite el ámbito del tipo a los supuestos en los que resulte atacado el bien jurídico protegido". Para este autor habrá que limitar las conductas de actividad profesional y de asesoramiento a "aque-

61 Delgado Gil, Delitos cometidos por los funcionarios públicos..., cit., p. 207, critica el empleo de dos términos calificando la clase de actividad incompatible con la función pública, pues equipara el asesoramiento a un "consejo profesional", por lo que no parecería existir diferencia con la actividad profesional y por tanto sería una mención "superflua", proponiendo de lege ferenda su supresión. Personalmente no prescindiría de dicha mención, pues la actividad profesional tiene que ser remunerada, cosa que no es necesaria en un asesoramiento.

62 Orts Berenguer, en González Cussac (coord.), Parte especial, $5^{\text {a }}$ ed., cit., p. 674 , señala que la actividad profesional, en principio, será "realizada de forma habitual".

63 Como decía Torío López, A.: "Fin de protección y ámbito de prohibición de la norma", Estudios Penales y Criminológicos t. X (1987), p. 384, "la tipicidad no se agota en la concordancia lógico formal (subsunción) del hecho en el tipo. La acción descrita típicamente ha de ser generalmente peligrosa para un bien jurídico", por lo que "la consideración lógico formal ha de ser integrada con la perspectiva material". 
llas conductas que tengan una clara entidad o importancia, sin que quepa entender que un simple consejo pueda constituir el presente delito" 64 . "El Juez o el Fiscal -continúa- que en una conversación con un Abogado, le sugieren la conveniencia de que presente un recurso, para poner un ejemplo entre los muchos posibles, no debe obviamente dar lugar a la aplicación del presente tipo" $"$.

Precisamente el Tribunal Supremo ha tenido ocasión de juzgar dos casos similares al que se acaba de mencionar: el ATS de 2 de junio de 2008 (caso de la Presidenta del TC) ${ }^{66}$ y la STS 19/2010, de 25 de enero (caso del Presidente de la AP Las Palmas ${ }^{67}$, y en ambos se llegó a la misma conclusión de que

64 Córdoba Roda, en Córdoba Roda/García Arán (dirs.): Comentarios..., cit., p. 2106.

65 La SAP Sevilla (Secc. 7ª) 62/2003, de 20 de noviembre, no vio ningún delito en la conducta de un policía local y licenciado en Derecho que se pone en contacto con la denunciante, que había tenido un accidente, para decirle que obrara por los cauces legales denunciando los hechos en el Juzgado, y no a través de los medios de comunicación.

66 Con motivo de la instrucción de una causa por asesinato, se interceptó una conversación telefónica entre la acusada y la Presidenta del TC. La instructora de esta causa dedujo testimonio por un posible delito del art. $441 \mathrm{CP}$, ya que estimó que la persona aforada "realiz[ó] aparentemente asesoramiento [a la acusada] sobre la forma de interponer recurso de amparo ante el mencionado Tribunal [el TC], del que ella sería parte, de la doctrina del mismo sobre un determinado punto, así como de "como aconsejarla de la mejor manera". El TS añade que la conversación concluye con la indicación por la aforada del nombre de dos personas que sí pueden realizar una eficaz labor de asesoramiento por su condición de especialistas.

67 También durante el transcurso de una conversación telefónica que estaba siendo grabada, con pleno conocimiento de que era el Magistrado Presidente de la Sección que habría de resolver el recurso de apelación contra un auto de prisión provisional y de que al día siguiente iba de presidir la correspondiente vista, dio las siguientes instrucciones para que su interlocutor las transmitiera a un tercero y éste, a su vez, a su Letrado: “... dile que no se enrolle, que explique las cosas claritas y sencillas; que explique la procedencia del dinero, que lo explique clarito y sencillo: Que lo explique de palabra pero de una forma sencilla, sin rollos y que diga que está dispuesto a prestar una fianza en la cantidad en la que se le diga. Bueno, pero dile eso, que no 
no había un asesoramiento típicamente relevante ${ }^{68}$. Para ello se acudió a argumentos como la adecuación social o la insignificancia de la conducta ${ }^{69}$. Sin embargo, desde mi modesto punto

se enrolle y que lo explique sencillo. Porque si no, predispone a la gente en contra, que se deje de rollos, vale".

La STSJ Canarias (Sala Civil y Penal) 1/2009, de 15 de abril, con una muy fundamentada argumentación había condenado al Magistrado, pero el TS la anuló.

68 En la STS 19/2010, de 25 de enero, se dice: "Es obvio que el asesoramiento típico no puede reservarse a planteamientos originales o construcciones jurídicas singulares, pues un entendimiento tan restringido del contenido típico haría de imposible realización el tipo penal en el ámbito de la aplicación del derecho, máxime cuando la acción se desarrolla con respecto a un Letrado con años de ejercicio profesional. Pero tampoco podemos integrar el elemento típico «asesoramiento» con las banalidades referidas a la conveniencia de la brevedad y claridad en el mensaje a verter en una vista oral, ni el ofrecimiento de fianza, pues ese extremo aparece anteriormente ofertado y, por otra parte, es una práctica habitual en el cuestionamiento de las medidas cautelares de contenido personal. Entre un asesoramiento de planteamiento original y los consejos irrelevantes, existe una situación intermedia que permite la tipicidad del art. 441 del Código penal". "Desde esta perspectiva -dice más adelante- la expresión de la conveniente brevedad y claridad en la expresión de la pretensión, así como el ofrecimiento de una fianza, no afecta al contenido esencial de la función y no integra el concepto típico de asesoramiento".

En el ATS del caso de la Presidente del TC se insiste también en ello: "no todo consejo emanado de una autoridad o funcionario público puede reputarse delictivo. Solo aquel que compromete la imparcialidad, que menoscaba el deber de exclusividad o que provoca una interferencia entre los intereses privados y los de naturaleza pública, puede ser objeto de persecución penal. Ninguna de estas notas concurre en el presente caso...".

69 Véase el comentario de Redondo Hermida, A.: "El concepto de conducta «socialmente adecuada» en el Auto del Tribunal Supremo de 2 de junio de 2008. (Comentario jurídico al caso «Presidenta del Tribunal Constitucional»)", en Diario La Ley n ${ }^{0} 7071$ (5 diciembre 2007), p. 8 ss. [=La Ley penal $\mathrm{n}^{\mathrm{o}} 55$ (2008)], quien maneja un concepto de asesoramiento, a mi juicio, excesivamente restrictivo, pues en el fondo lo viene a equiparar con un asesoramiento profesional, ya que tendrían que aparecer, entre otras, "actuaciones consistentes en entrevistas con los asesorados, entrega de documentación, confección de escritos jurídicos y evaluación de expectativas según las diversas estrategias posibles". 
de vista, ninguno de estos criterios resuelve satisfactoriamente el problema ${ }^{70}$.

El argumento de la insignificancia de la conducta, aparte de la imprecisión que conlleva, considero que no tiene por qué descartar la concurrencia de un peligro relevante para el bien jurídico protegido ${ }^{71}$. Una peligrosidad mínima, que no imposibilidad absoluta, realizada con cierta intención puede ser ya suficiente para afirmar la imputación ${ }^{72}$. Por tanto, quien da un consejo que represente un incremento del peligro para la imparcialidad/objetividad, por ínfimo que éste sea, pero que se hace con una determinada intención, dicho peligro puede resultar ya adecuado para imputar el delito del art. $441 \mathrm{CP}$ (infra 9.4).

70 Sobre el principio de insignificancia y la adecuación social aplicados al delito de cohecho pasivo impropio, véase el reciente trabajo de GómEz Rivero, C.: "Derecho penal y corrupción: acerca de los límites de lo injusto y lo permitido", en Estudios Penales y Criminológicos t. XXXVII (2017), p. 249 ss. Menciona estos dos casos (p. 278 n. 38), aunque sin pronunciarse al respecto.

71 Según Gómez Rivero, el principio de insignificancia descansa sobre dos presupuestos: uno, que se constate la efectiva producción de una lesión o puesta en peligro del bien jurídico; y dos, que ésta presente una escasa lesividad en términos cuantitativos [EPC t. XXXVII (2017), p. 266]. Por estos motivos la aceptación del principio de insignificancia "resulta altamente cuestionable" (p. 267) y en el ámbito de la corrupción el valor del mismo "est[á] llamado a ser prácticamente inexistente. En un terreno en el que el legislador, lejos de dar muestras de la renuncia a la pena sobre la base de la insignificancia material de la conducta manifiesta una clara tendencia a incriminar prácticamente todos los comportamientos desviados como expresión de una suerte de tolerancia cero contra la corrupción, difícilmente podrán defenderse espacios de impunidad extrarradio de la letra de la ley" (p. 268).

72 Recuérdese, por ejemplo, el caso de Thyrén del inexperto tirador a muy larga distancia. Véase, al respecto, por todos, ToRío LóPEZ, A.: "Naturaleza y ámbito de la teoría de la imputación objetiva", $A D P C P$ 1986, p. 38, para quien una peligrosidad mínima de la acción puede fundamentar en los delitos dolosos la imputación, mientras que en los imprudentes igual no lo haría. También IDEM, "Fin de protección y ámbito de prohibición de la norma", $E P C$ t. X (1987), p. 383 ss.; IDEM, “Acción peligrosa y dolo", $C D J$ t. XXXIII (1994), p. 155 ss. 
La adecuación social igualmente es un criterio muy genérico, con el peligro que ello entraña para los principios de taxatividad y certeza. Pero es que además la adecuación social tampoco tiene por qué ser un criterio decisivo a la hora de delimitar el espacio punible. Es posible que una acción socialmente inadecuada no sea punible. No hay sólo acciones socialmente aceptadas, por un lado, y acciones punibles, por otro, sino que en medio también hay muchas acciones que la sociedad no acepta, pero que no son lo suficientemente graves como para ser consideradas relevantes para el Derecho penal. Puede haber un ilícito administrativo, por ejemplo, pero no un ilícito penal, y no se puede decir que ello sea una conducta adecuada socialmente.

No obstante, la idea de la adecuación social es una idea tendencialmente correcta para perfilar el presente tipo delicti$\mathrm{vo}^{73}$, aunque considero que mejor sería sustituirla por otros

Resulta significativo en este sentido lo que dice el TS a propósito del envío por parte del Presidente del Tribunal a una de las partes de un modelo para interponer recurso contencioso-administrativo en la STS 362/2014, de 25 de abril (caso ITV Cataluña): "La representación del acusado insistió en el acto del plenario que estábamos ante un mero formulario, fácilmente accesible a través de Internet, y que como tal carecía de relevancia alguna. Pero cabe indicar al respecto que, sin negar que lo que se envía es un modelo de escrito para presentar el recurso, ha de valorarse quién lo envía, que es el Presidente de la Sección del Tribunal que va a conocer del mismo [destacó también esto la STSJ Canarias (Sala Civil y Penal) 1/2009, de 15 de abril (caso del Presidente de la AP de Las Palmas), anulada posteriormente por la STS 19/2010, de 25 de enero]. No podemos concluir pues que dicho envío sea una banalidad o un acto carente de importancia (también se protege la apariencia de imparcialidad). La remisión de una de las partes de un modelo para preparar un escrito que va a presentarse en el tribunal, y principalmente por el juez o magistrado que va a conocer del asunto en cuestión, como fue el caso, en modo alguno puede calificarse de acto irrelevante porque afecta al contenido esencial de la función judicial objetiva e imparcial" (f.j. $3^{\circ}$ punto 3).

73 En este sentido, Gómez Rivero, EPC t. XXXVII (2017), p. 270, señala que la adecuación social comporta la renuncia a la pena sobre la base de la ausencia de lesividad material al bien jurídico, por lo que puede ser más aceptable que el principio de insignificancia. Por ello concluye que "si bien es cierto que tal aspecto [el amplio margen de discrecionalidad que estos 
criterios interpretativos más precisos, como el riesgo jurídicamente permitido y una interpretación restrictiva orientada al fin de protección de la norma. El riesgo jurídicamente permitido lo establece la normativa extrapenal correspondiente. De hecho el art. $441 \mathrm{CP}$ se remite expresamente a dicha normativa (infra 8). Por lo que al otro criterio se refiere, una interpretación restrictiva orientada al fin de protección de la norma, considero que habrá que valorar si el asesoramiento presenta o no una clara referencia de sentido delictivo, lo cual se determinará en función de la finalidad a la que sirve (infra 9.4).

Conforme a estos parámetros, considero que en el caso del Presidente de la AP de Las Palmas sí habría habido un asesoramiento punible por poner en peligro de modo relevante la la imparcialidad y objetividad de la Administración de Justicia, mientras que en el caso de la Presidenta del TC no lo aprecio.

\section{Objeto material: en asunto en que deba intervenir o haya intervenido por razón de su cargo, o en los que se tramiten, informen o resuelvan en la oficina o centro directivo en que estuviere destinado o del que dependa}

El «asunto» en el que el funcionario interviene vendría a ser el objeto material sobre el que recae la acción. No basta para que exista delito con compaginar a la vez cualquier actividad privada con el desempeño de un empleo público, sino que tiene que versar sobre un determinado asunto: 1) un asunto en el que deba intervenir o haya intervenido por razón del cargo; o 2) un asunto de los que se tramiten, informen o resuelvan en la oficina o centro directivo en que estuviere destinado o del que dependa.

argumentos dejan a los jueces] añade una importante cuota de inseguridad y que, por ello, pudiera ser acreedor de un juicio negativo, entiendo que en el ámbito... de la corrupción, lejos de contemplarse como una tacha, aquella necesidad de la interpretación judicial se presta a valorarse como un valioso instrumento para dejar fuera del ámbito de lo punible aquellas conductas que debieran ventilarse en otros ámbitos, ajenos al orden penal” (p. 300). 
Delgado Gil ha analizado detenidamente este elemento y primero aclara, relacionándolo con el art. $439 \mathrm{CP}$, cómo se debe interpretar el verbo «intervenir», considerando que es equivalente a tramitar, informar o resolver ${ }^{74}$. Luego examina qué ámbito es el que tiene el asunto administrativo en que se debe intervenir, que es doble: en asunto que deba intervenir o haya intervenido, por un lado, y por otro, en asuntos de los que se tramiten, informen o resuelvan en la oficina o centro directivo en el que estuviere destinado o del que dependa. "En el primero de los casos -dice-, se pone en riesgo tanto la objetividad como la imparcialidad con que ha de actuar el funcionario en el ejercicio de su cargo, pero no así en el segundo, en que sólo de forma más remota se ven estos principios comprometidos" ${ }^{\prime 75}$. Por eso considera que "de lege ferenda sería preferible la supresión de este inciso del precepto. La interferencia en el ejercicio de funciones públicas que puede producirse cuando el funcionario tenga intereses privados en cuestiones sobre las que debe decidir como servidor público, puede más fácilmente producirse cuando el funcionario toma parte directamente que cuando es otro quien lo hace. Cuando el asunto se tramite, informe o resuelva en la oficina o centro directivo en que esté destinado o del que dependa el funcionario, éste es posible que tenga alguna influencia en las personas que componen aquellos lugares, pero no es seguro"76.

Comparto esta configuración del delito, que viene a ser, para el primer supuesto un delito de peligro concreto, y para el

74 Delgado Gil, Delitos cometidos por funcionarios públicos..., cit., p. 201; IDEM, "La nueva redacción del delito de participación indebida del funcionario en negocios (art. $439 \mathrm{CP}$ ) a partir de la LO 5/2010. La ampliación del sujeto activo y de la pena", en La Ley penal n 78 (2011), p. 40, considerando adecuado que el delito englobe las tres situaciones mencionadas.

75 Delgado Gil, Delitos cometidos por funcionarios públicos..., cit., p. 202.

76 Delgado Gil, Delitos cometidos por funcionarios públicos..., cit., p. 203. También Nieto Martín, en Eurodelitos de corrupción y fraude..., cit., p. 116, es partidario de suprimir este segundo supuesto. Sobre esta propuesta de lege ferenda me pronuncio infra 9.3 . 
segundo supuesto un delito de peligro hipotético o posible ${ }^{77}$. La ofensividad de este segundo supuesto es cierto que es más remota, pero, en mi opinión, su incriminación puede estar justificada por el hecho de que, en un asunto concreto que se esté tramitando en la oficina o centro en que esté adscrito, el funcionario se pone al servicio o bajo la dependencia de entidades privadas o particulares. Además, cuanto más alta sea la jerarquía del funcionario, mayor es su capacidad de intervención, por lo que también resulta más oportuno que el margen de participación en actividades profesionales sea menor. Del mismo modo, cuanto más cercana físicamente hablando sea la confluencia entre las actividades privadas y las públicas, mayor será la posibilidad de comprometer la imparcialidad del funcionario ${ }^{78}$. Igualmente,

77 También otros autores han hablado de estas dos modalidades de delitos de peligro: concreto para la primera y abstracto para la segunda. Así, MoRALES Prats/Rodríguez Puerta, en G. Quintero Olivares (dir.), Comentarios..., cit., p. 1801; Morillas Cueva, en Morillas Cueva (dir.): Sistema de Derecho Penal. Parte especial, $2^{\text {a }}$ ed., Madrid, 2016, p. 1192; Nieto MarTín, en Eurodelitos de corrupción y fraude..., cit., p. 112, quien señala que el art. 441 $\mathrm{CP}$ comprende dos tipos de conflictos de intereses distintos: "uno de naturaleza real o actual... y otro potencial", siendo difícil de comprender la equiparación a efectos de pena de ambas posibilidades. Entre la jurisprudencia, por ejemplo, las SSAP Barcelona (Secc. $5^{\text {a }}$ ) de 23 de febrero de 2000; Lleida (Secc. $1^{a}$ ) 362/2013, de 23 de noviembre; Sevilla (Secc. $1^{\text {a }}$ ) 169/2005, de 16 de marzo; AAP Sevilla (Secc. $3^{\text {a }}$ ) 396/2004, de 7 de octubre.

Por el contrario, la STS 765/2014, de 4 de noviembre, afirma que "el delito se consuma... sin necesidad de que exista un concreto peligro, que el legislador no ha querido llevar al tipo como elemento normativo, ni tampoco un peligro abstracto, pues la ratio essendi de la incriminación de la conducta, no es el riesgo de que el interés público se vea sacrificado por el privado, sino directamente la infracción de los deberes de incompatibilidad, abstención y exclusividad".

78 Por eso habrá que interpretar de un modo restrictivo la referencia a la «oficina o centro directivo». Con estos términos -dice Catalán Sender, $A P \mathrm{n}^{\circ}$ 29 (1998), p. 532- "es evidente que por un lado no se refiere a todo el Departamento, Ministerio o Corporación, [pero] por otro lado puede ser más amplio que el concepto de oficina". También García España, $J p D \mathrm{n}^{\mathbf{o}} 48$ (2003), p. 61 lo circunscribe a "la dependencia administrativa directamente competente..., con independencia de que... dicha dependencia se subdivida en unidades". 
cuanto más próxima en el tiempo sea la confluencia entre las actividades privadas y las públicas, mayor será la posibilidad de comprometer la imparcialidad del funcionario.

Mediante estas dos conductas se trata de abarcar cualquier conflicto de intereses entre la actividad privada y la correspondiente función pública ${ }^{79}$. Así, el desempeño de la

La STS 698/2011, de 22 de junio, absolvió a un psiquiatra de un hospital que emitió diversos informes a pacientes que acudían a su consulta privada con el fin de que obtuviesen una incapacidad laboral, porque estima que la «oficina o centro directivo de destino o de dependencia» se ha de identificar, exclusiva y limitadamente, como el que «tramita, informa o resuelve» el procedimiento administrativo. Y el destino o dependencia del autor, respecto de él han de ser directos y referidos al órgano o centro directivo que lleva a cabo la tramitación o emite el informe o la resolución".

La SAP Albacete (Secc. 1 $1^{\mathrm{a}}$ ) 6/2003, de 19 de febrero, absolvió del delito del art. 441 CP a un funcionario destinado en la Secretaría General de la Delegación de la Agencia Tributaria de Albacete que confeccionó diversas declaraciones del IRPF por las que cobraba 5.000 pesetas, ya que "aunque de modo formal dependía de la Agencia Tributaria, realmente... de quien efectivamente dependía era de la Secretaría General", que tiene unas competencias centradas en temas referentes a recursos humanos, ajenas e independientes, por tanto, de las que corresponden a la Agencia Tributaria en punto a liquidación, sanciones y recaudación de impuestos. En términos parecidos, la SAP Asturias (Secc. $3^{\mathrm{a}}$ ) 165/2003, de 24 de septiembre, absolvió a un auxiliar administrativo adscrito a funciones censales e IVA que colaboraba en la asesoría fiscal de su cuñada en la confección de declaraciones del IRPF, pues "carecía de competencia alguna que en definitiva le permitiera interrelacionar y-simultanear-ambas facetas, pública y privada, sin olvidar la necesidad de que la función pública lleve aparejada una cierta capacidad de gestión y decisión que no concurre en el acusado dada su categoría de auxiliar administrativo". En el mismo sentido, la SAP Pontevedra (Secc. $4^{\mathrm{a}}$ ) 26/2006, de 24 de febrero.

La SAP Cádiz (Secc. 1ª) 26/2011, de 14 de febrero, condenó a un funcionario que estaba prestando servicios en la Oficina de Respuesta Unificada para las Pymes (ORU), porque tiene la condición de Unidad Administrativa Gestora con respecto a los órganos competentes por razón de la materia; además, los servicios contratados de asesoramiento y actuación por encargo, económicamente retribuidos, coincidían plenamente con sus cometidos funcionariales.

79 Morales Prats/Rodríguez Puerta, en Quintero Olivares (dir.), Comentarios..., cit., p. 1801, al calificar este delito como una mera puesta en peligro del principio de imparcialidad señalan que "se trata de evitar la posible 
función pública puede ser posterior («deba intervenir») $)^{80} \mathrm{o}$ anterior («haya intervenido») ${ }^{81}$ al ejercicio de la actividad profesional o de asesoramiento, y por supuesto, también simultáneo. Aunque del tenor literal del art. $441 \mathrm{CP}$ se pudiera desprender otra cosa, en coherencia con lo fijado en el art. 12.1 a) Ley $53 / 1984$, hay que considerar típico el desempeño contemporáneo de la actividad privada y de la función pública. Es más, se ha dicho con razón que en este caso la "carga de antijuridicidad es incluso mayor" $" 82$ que en los otros, y no dejan de ser los supuestos más frecuentes que enjuician los Tribunales.

La normativa administrativa ha venido a establecer ciertos límites temporales, tanto antes como después, dentro de los cuales se presume iuris et de iure que existe un conflicto de intereses ${ }^{83}$ y que, por tanto, se compromete la imparcialidad del funcionario. Así, en el caso de que la actividad privada sea anterior a la pública, el art. 23.2 Ley 40/2015 ha establecido como motivo de abstención el haber prestado a persona natural o jurídica interesada directamente en el asunto «en los dos últimos años servicios profesionales de cualquier tipo y en cualquier circunstancia o lugar». Del mismo modo, el art. 12.1 a) Ley 53/1984 ha establecido la incompatibilidad de actividades

confluencia en el funcionario de intereses públicos y privados que puedan, directa o indirectamente, incidir en el ejercicio de sus funciones", pero no es necesario que "el funcionario se haya dejado influir en su actividad pública por intereses privados, sino únicamente que ello pueda ser posible atendida la duplicidad, pública y privada, de la actividad profesional que desempeña".

80 Por ejemplo, la STS 765/2014, de 4 de noviembre, condenó a dos arquitectos honoríficos de un Ayuntamiento por su intervención en la tramitación administrativa relativa a la aprobación y ejecución de unos proyectos de urbanización que habían elaborado para una empresa privada de la que eran socios y coadministradores.

81 García España, $J p D$ n $^{\circ} 48$ (2003), p. 60, considera en los casos "en los que la actividad profesional o el asesoramiento es posterior a su intervención como funcionario... la conducta está excesivamente alejada del bien jurídico".

82 Alegre Ávila, Tratado III, p. 630.

83 Carro Fernández-Valmayor, J.L.: "Ética pública y normativa administrativa", en Revista de Administración Pública 181 (2010), p. 25. 
privadas con la función pública en aquellos asuntos en los que el funcionario «haya intervenido en los dos últimos años». Aunque estas normas no son permisiones expresas, sino que más bien son prohibiciones, se puede entender que hay una presunción legal de que esta actividad privada lejana en el tiempo no ha podido «impedir o menoscabar el estricto cumplimiento de sus deberes o comprometer su imparcialidad o independencia» (art. 1.3 Ley 53/1984). Por tanto, habría que excluir estos supuestos del ámbito del art. $441 \mathrm{CP}^{84}$.

\section{Remisión normativa: fuera de los casos admitidos en las leyes o reglamentos}

La expresión «fuera de los casos admitidos en las leyes o reglamentos» debe tratarse como un elemento normativo del tipo $^{85}$, más que como una referencia legal expresa a la ausencia de causas de justificación ${ }^{86}$. Esto tiene como consecuencia que

84 Piñol Rodríguez, J.R., en Suárez-Mira Rodríguez (coord.), Manual... II, cit., p. 550, menciona expresamente sólo el límite temporal cuando la actividad privada es posterior a la intervención en asuntos públicos. También Alegre Ávila, Tratado III, p. 629.

85 Una expresión similar aparece, por ejemplo, en los arts. 145 (aborto), 163 (detenciones ilegales por particular), 167 (detenciones ilegales por funcionario), 198 (descubrimiento y revelación de secretos por funcionario), 204 (allanamiento por funcionario), 260 (favorecimiento de acreedores), 500 (detención ilegal de parlamentarios), 538 (censura), 540 (disolución de reunión), 541 (expropiación).

García España, $J p D$ n $^{\circ} 48$ (2003), p. 61, equipara esta expresión a «sin estar legítimamente autorizado» utilizada en el art. $172 \mathrm{CP}$ y lo configura como un elemento descriptivo.

86 Mir Puig, $C D J$ n $^{\circ} 30$ (1996), p. 329, aunque plantea la duda de si dicha expresión encarna un elemento normativo del tipo o únicamente condiciona la justificación de la conducta típica, se decanta por lo primero ya que "en realidad la justificación de la conducta habría tenido efecto igualmente, aun sin estas cláusulas negativas [se refiere también a la del art. 163.4 CP], por la vía de la eximente general de ejercicio de un derecho (art. $20.7^{\circ} \mathrm{CP}$ )", lo cual puede "servir como argumento favorable a conceder a estas cláusulas un papel que vaya más allá de recordar lo ya previsto por la eximente general”. Pero también considera que esta cláusula negativa puede verse como 
la acusación deberá probar la presencia de este elemento típico ${ }^{87}$. Que sea un elemento del tipo se fundamenta en el hecho de que el reconocimiento de compatibilidad con actividades privadas reviste carácter reglado, es decir, se da siempre que no concurran las prohibiciones establecidas en la ley ${ }^{88}$. Es importante subrayar esto, ya que la incriminación de la conducta depende única y exclusivamente del sistema normativo de incompatibilidades y no del acto administrativo de reconocimiento o no de la compatibilidad $^{89}$. Lo contrario sería tanto como supeditar la antijuridicidad de la conducta a lo que diga el acto administrativo y no a

expresiva de un "elemento de valoración global del hecho", lo cual obligaría a "distinguir según que el error verse sobre la base fáctica del elemento o sobre la admisión jurídica misma de la conducta. La primera clase de error sería de tipo, pero la segunda sería de prohibición" (p. 330). Y así: "El funcionario que cree legalmente compatible su actividad por desconocimiento del Derecho, incurriría en el $\mathrm{n}^{\circ} 3$ del art. 14, y sería punible si su error fuera vencible", mientras que "si se confunde acerca de la naturaleza del asunto objeto de su asesoramiento, el error sería incluible en el $\mathrm{n}^{\circ} 1$ del art. 14, y sería impune aunque fuera vencible".

La STS 484/2008, de 11 de julio, considera que "constituye una condición negativa" del tipo penal [también la SAP Barcelona (Secc. 21ª) 718/2011, de 23 de mayo].

87 Muñoz Cuesta, en RJA n ${ }^{\circ} 19$ (2008).

88 El principio general es el de compatibilidad entre actividades públicas y privadas. Solamente se prohíben, en atención a lo dispuesto en el art. 1.3 y 11 Ley 53/1984, las actividades privadas que «se relacionen directamente con las que desarrolle el Departamento, Organismo o Entidad donde estuviera destinado». Y en todo caso, resultan incompatibles las enumeradas en el art. 12 de dicha Ley. A contrario sensu las actividades no previstas en dichos preceptos podrán ser llevadas a cabo «previo reconocimiento de compatibilidad» (art. 14 Ley 53/1984).

89 Así, Alegre Ávila, Tratado III, p. 632, considera que la conducta del funcionario "sólo será típica si la actividad privada no es susceptible del aludido reconocimiento de compatibilidad, no, por tanto, cuando, siéndolo, el interesado no haya obtenido el oportuno reconocimiento... cuya falta de solicitud... será, a lo sumo, constitutiva de infracción disciplinaria"; DeLGADO GIL, Delitos cometidos por funcionarios ..., cit., p. 212, para quien "si la infracción de las normas sobre incompatibilidades únicamente consiste en no haber solicitado o tramitado la solicitud de autorización del ejercicio de la actividad (pero, de haberlo hecho, hubiera sido consentida), en ningún 
lo que disponga la ley, lo que en última instancia implicaría una criticable supeditación del ius puniendi a la Administración ${ }^{90}$. Por tanto, este delito hay que concebirlo como una ley penal en blanco $^{91}$.

Muñoz Cuesta, RJA n ${ }^{\circ} 19$ (2008), comenta la STS 484/2008, de 11 de julio [que confirma la SAP Barcelona (Secc. 7a) 754/2007, de 19 de abril], relativa al caso de un Inspector de Trabajo que asesoró a una empresa que estaba siendo inspeccionada por otros inspectores. En dicha sentencia se cuestionó si dicho Inspector había actuado o no fuera de los casos admitidos en las Leyes,

caso será posible el castigo penal"; MIR PUIG, Los delitos contra la Administración pública ..., cit., p. 368, según el cual si la actividad o asesoramiento son compatibles y falta la autorización debida "la realización de la actividad o asesoramiento paralelos, dará lugar como máximo a una infracción disciplinaria administrativa".

90 Véase, por ejemplo, la SJP de Orihuela 141/2016, de 8 de junio, que a pesar de la delegación de competencias, condenó al Alcalde de una localidad de Alicante, por administrar simultáneamente una empresa de construcción que obtuvo varias licencias emitidas por el área de Urbanismo del mismo Ayuntamiento, ya que conservaba la competencia originaria, pues "podía volver a traer a sí las competencias en cualquier momento sin existir justificación ni limitación a este derecho".

Compárese, en cambio, con el AAP Ávila (Secc. 1 ${ }^{\text {a }}$ ) 205/2010, de 25 de noviembre, que confirmó el sobrebeseimiento en un caso en que el Alcalde de una pequeña localidad abulense era a la vez administrador único de una constructora que promovió la aprobación de sendos proyectos para la construcción de 29 viviendas en unos terrenos de dicha localidad. En los plenos de aprobación de tales proyectos el Alcalde "se abstuvo" y luego las licencias de ocupación de tales viviendas fueron firmadas por el Teniente de Alcalde "por delegación". Se concluye que el Alcalde "no tomó parte en la regularización urbanística de esos inmuebles", pero la mera delegación formal de competencias dio al traste en este caso el examen de la posible concurrencia de los restantes elementos del delito del art. $441 \mathrm{CP}$.

91 Así lo califica expresamente, entre otros, Mir PuIG, NEJ Seix t. XVII (1982), p. 329; IDEM, $C D J \mathrm{n}^{\circ} 30$ (1996), p. 321. También, entre otros, CRESPO BARQUERo, en Serrano Butragueño (coord.): Código Penal II, p. 2441; Morillas Cueva, Sistema de Derecho penal, $2^{\mathrm{a}}$ ed., cit., p. 1193; Muñoz Conde, Parte Especial, $21^{\text {a }}$ ed., cit., p. 895.

En contra, Garcés Carbonell, Foro FICP n n 2013-2, p. 305, aunque ella misma reconoce que la integración del tipo "requiere de modo ineludible la remisión a la legislación en materia de incompatibilidades y de conflictos de intereses". 
ya que el art. 3.2.1 de la Ley de Ordenación de la Inspección de Trabajo y Seguridad Social de 1997, autoriza a los Inspectores a facilitar información técnica a empresas y trabajadores con ocasión del ejercicio de su función inspectora. Sin embargo, este asesoramiento sólo está permitido si es "con la finalidad de que mejore o reduzca las causas que motivan la anomalía en la actividad empresarial o laboral que es objeto de inspección, no con otra finalidad", de tal manera que "si se hace con el objetivo de limitar la función de la administración quedará fuera del caso permitido por la ley de que habla el art. $441 \mathrm{CP}$ ".

La STS 362/2014, de 25 de abril, también examinó si la actividad del Magistrado podía quedar amparada por la posibilidad prevista en el art. 77 de la Ley de la Jurisdicción Contenciosa Administrativa de una mediación. Sin embargo, el TS lo descarta por dos razones. Una, porque los supuestos intentos de mediación sólo tuvieron como protagonistas, además de a las abogadas de la Generalidtat, a una de las partes litigantes, CERTIO, y a no las otras dos entidades codemandadas. Y otra, porque se ocultó a las letradas convocadas al encuentro que las personas allí presentes representaban precisamente a una de las partes en conflicto.

\section{La diferencia entre el ilícito administrativo y el ilícito pe- nal: actuar bajo la dependencia $o$ al servicio de entidades privadas o de particulares}

\subsection{El presupuesto: conflicto de intereses entre públi- cos y privados}

Para que sea punible la actividad profesional o de asesoramiento tiene que llevarse a cabo «bajo la dependencia o al servicio de entidades privadas o de particulares». El tipo excluye del ámbito de lo punible cualquier actividad profesional o de asesoramiento llevada a cabo dentro del sector público, aunque también pueda existir una incompatibilidad y pueda dar lugar a la correspondiente responsabilidad disciplinaria ${ }^{92}$. El principio

92 Así, entre otros, Alegre Ávila, Tratado III, p. 627; Córdoba Roda, en Córdoba Roda/García Arán (dirs.), Comentarios..., cit., p. 2107; Delgado GiL, 
general es el de dedicación a un solo puesto de trabajo dentro del sector público, salvo excepciones (art. 1.1 Ley 53/1984) ${ }^{93}$. Los conflictos de intereses punibles tienen que ser, por tanto, entre intereses públicos e intereses privados.

Pero esta conclusión de que la actividad incompatible con la función pública tiene que ser privada se extrae, no tanto por este requisito típico que se está analizando ahora, como de la propia referencia a que la actividad tiene que ser «profesional o de asesoramiento», y sobre todo, como señala DeLGADO GiL, también desde una interpretación teleológica en función del principio de imparcialidad administrativa, pues hay que considerar que "se trata de que los servicios que han de prestar los funcionarios no se vean interferidos por intereses privados" $" 94$.

Delitos cometidos por funcionarios públicos ..., cit., p. 206; MuÑoz Cuesta, $R J A \mathrm{n}^{\circ} 19$ (2008); Orts Berenguer, en González Cussac (coord.), Parte Especial, $5^{\text {a }}$ ed., cit., p. 674 , dice que no se incurre en responsabilidad criminal "cuando se trabaja para otra entidad pública".

No puede cometer este delito, por tanto, el Inspector del Banco de España nombrado para desempeñar el cargo de administrador provisional de una Caja de Ahorros intervenida [AAP Madrid (Secc. 17ª) 954/2013, de 15 de julio]; ni un trabajador agrícola contratado para la limpieza de caminos en el propio municipio en el que es concejal del Ayuntamiento (STS 2125/2002, de 7 de enero de 2003). En esta resolución se afirma que "la conducta típica no abarca el trabajo o actividad realizados para la propia entidad pública de la que es agente el funcionario... o, incluso, para otra entidad pública, como sería el caso típico de un funcionario de la Administración central que realizara alguna actividad para un órgano autonómico o local, aunque obviamente incurriría en la correspondiente responsabilidad administrativa si lo hiciera sin la necesaria autorización" (igual la STS 1189/2010, de 30 de diciembre). En términos parecidos, la STS 677/2014, de 22 de octubre, confirmó la absolución de un Secretario-Interventor que fue nombrado ilegalmente también como recaudador, al entender que la actividad punible del art. $441 \mathrm{CP}$ "tendría que haberse desarrollado al servicio de terceros particulares, y lo cierto es que aquí se produjo en el marco de la entidad local".

93 Dichas excepciones se refieren a los ámbitos docente y sanitario, a los cargos políticos electivos de los Parlamentos autonómicos y de las Corporaciones locales y a la pertenencia a consejos de administración de entidades o empresas públicas o privadas. Para compaginar estos dos empleos públicos, se requiere autorización, que es discrecional y siempre «en razón del interés público» (arts. 3 ss. Ley 53/1984).

94 Delgado Gil, Delitos cometidos por funcionarios públicos..., cit., p. 206. 
Catalán Sender ha querido ver otro significado en esta expresión, al señalar que "la idea de dependencia parece hacer referencia al contrato de trabajo" y "el servicio parece aludir a contratos extralaborales (arrendamiento de servicios civil, etc.)"95. Si esto es así, el art. $441 \mathrm{CP}$ estaría excluyendo la posibilidad de que el sujeto realice una actividad profesional autónoma. Sin embargo, como dice Delgado Git, "así como la 'dependencia' de entidades privadas o particulares sugiere, ahora sí, que el funcionario se encuentre en una situación de subordinación respecto de terceros, la mención a que la actividad pueda realizarse 'al servicio' de otros no necesariamente implica lo anterior", y ello precisamente, continúa, porque se ha querido "recoger todas las posibilidades en las que el funcionario puede vulnerar la imparcialidad y objetividad con que debe actuar" ${ }^{\prime 96}$. Además, cabe decir en contra de aquella interpretación que el asesoramiento puede ser «accidental», lo cual no necesariamente se va a formalizar en un contrato de arrendamiento de servicios.

\subsection{La titularidad de los intereses privados: propios o ajenos}

Otra cuestión que plantea este requisito es si quedan comprendidos dentro del ámbito del tipo los supuestos en que el funcionario actúa en interés propio. Parece que al hablar de «entidades privadas o de particulares» se estaría excluyendo aquellos casos en los que el funcionario trabaja para sí mismo. CATALÁN SENDER, no sin dudas al respecto, pues dice que el precepto es "enrevesado", considera que éste abarcaría también los casos

95 Catalán Sender, $A P$ n $^{\circ} 29$ (1998), p. 531. En el mismo sentido, también Alegre Ávila, Tratado III, p. 628.

96 Delgado Gil, Delitos cometidos por funcionarios públicos..., cit., p. 210, "el estar al servicio de entidades privadas o de particulares - dice- no implica necesariamente una situación de jerarquía". Y pone el siguiente ejemplo: "está al servicio de particulares el aparejador municipal de un ayuntamiento que realiza actividades profesionales como aparejador en obras privadas (sean éstas habituales o no) cuando luego va a tener que intervenir en el asunto por razón de su cargo", con cita de la STS 867/2003, de 22 de septiembre [que confirma la SAP Madrid (Secc. 16 ${ }^{a}$ ) 190/2001, de 15 de junio]. 
en que el funcionario realiza la actividad para sí mismo, pese a que "no depende de nadie y es dudoso que preste algún servicio a otra persona". Sin embargo, él entiende que el "escollo puede salvarse" conectando la expresión «al servicio de entidades privadas o de particulares» con la locución «por sí», que según él "hubiera bastado para tipificar correctamente el precepto, siendo innecesaria la [otra] locución"

Comparto esta conclusión de que también tendría responsabilidad criminal por este delito el funcionario que actúa en su propio interés. Sin embargo, lo importante para alcanzar tal conclusión no estriba tanto en la cláusula «por sí o por persona interpuesta», como en el otro elemento del tipo «bajo la dependencia o al servicio de», interpretado teleológica y valorativamente en relación con el bien jurídico protegido ${ }^{98}$. Además, gramaticalmente también se puede considerar que el funcionario que trabaja para sí mismo lo hace «al servicio de particulares»; y sistemáticamente todas las normas administrativas sobre la

97 Catalán Sender, $A P \mathrm{n}^{\circ} 29$ (1998), p. 532.

98 Sancinetti, M.: "Negociaciones incompatibles con el ejercicio de funciones públicas”, en Anuario de Derecho Penal y Ciencias Penales 1986, p. 877 ss., al comentar el art. $265 \mathrm{CP}$ argentino (equivalente a nuestro art. $439 \mathrm{CP}$ ), que no aclaraba si el funcionario debía «interesarse» en favor de un tercero o propio, consideró, en contra del parecer entonces mayoritario en su país, que el interés podía ser tanto propio como ajeno. Esta interpretación, por cierto, acabó plasmándose expresamente en la redacción del art. $265 \mathrm{CP}$ argentino ahora vigente a través de la Ley de ética de la función pública de 1999. Aunque el problema era el inverso al que estamos ahora abordando, sin embargo, creo que la fundamentación teleológica con la que sostenía su parecer es perfectamente trasladable a nuestro art. 441 CP. Decía así: "desde el punto de vista de la transparencia e imparcialidad de la actuación de los órganos administrativos, es absolutamente irrelevante que la finalidad espuria consista en beneficiarse a sí mismo o a un tercero. La imparcialidad de la Administración no se halla más afectada por el hecho de que la desviación de poder tienda a beneficiar al autor, que a cualquier otro".

Sobre la regulación argentina, véase, por todos, BAsílico, R.A.: Negociaciones y actividades prohibidas a los funcionarios públicos y de los abusos en el ejercicio de su función, Tesis doctoral, Universidad de Sevilla, 21 de junio de 2014 (disponible en https://idus.us.es/xmlui/handle/11441/58681). 
materia mencionan como motivos de abstención o de incompatibilidad el tener «intereses propios» en el asunto ${ }^{99}$. Pero antes de exponer dónde radica el núcleo del injusto del delito que se está analizando, quiero abordar algunas propuestas que se han formulado respecto a la desincriminación de estas conductas.

\subsection{Propuestas de desincriminación y de sanción exclusivamente en la vía administrativa}

Si el art. 441 CP comprende aquellos supuestos en los que la autoridad o funcionario compagina simultáneamente la actividad pública con la actividad privada incompatible, se plantea entonces el problema de cómo delimitar un simple ilícito administrativo del ilícito penal. Este problema ha llevado a un importante sector doctrinal a abogar por la supresión del art. 441 CP, y así, Morales Prats y Rodríguez Puerta consideran que "este delito viene... a incriminar aquellos incumplimientos graves de las leyes de incompatibilidades en la Administración, elevando a la categoría de delito meras infracciones disciplinarias", concluyendo de lege ferenda que "lo más adecuado sería transferir al Derecho Administrativo la solución de esta clase de conflictos"100. Aunque en última instancia haya que coincidir en este planteamiento de que lo mejor sería que estos asuntos se resolviesen en el ámbito administrativo sancionador, sin embargo, dada la actual situación de ineficacia del sistema de control de conflicto de intereses por parte del Derecho administrativo (supra 4), en estos momentos no se puede compartir esta propuesta de desincriminación ${ }^{101}$.

99 Véase, por ejemplo, el art. 23.2.a) Ley 40/2015 sobre los motivos de abstención; o el art. 11.2.a) Ley 3/2015 sobre la definición del conflicto de intereses para los altos cargos del Gobierno.

100 Morales Prats/Rodríguez Puerta, en Quintero Olivares (dir.): Comentarios..., cit., p. 1801. Citados estos autores en este punto por la SAP Sevilla (Secc. $7^{\mathrm{a}}$ ) 62/2003, de 20 de noviembre.

101 Tiene también razón García EsPaÑa, en $J p D n^{\circ} 48$ (2003), p. 51, cuando advierte que elevar simples infracciones administrativas al rango penal no consigue una mejor eficacia de su persecución, "sino, antes al contrario, un ilegítimo efecto simbólico, el que deriva de que dichos comportamientos estén contemplados por el sector del ordenamiento jurídico más represivo". 
Más matizada es la propuesta desincriminadora de DeLGADO GIL, quien sólo se refiere a la segunda modalidad (asuntos que se tramiten, informen o resuelvan en la oficina o centro directivo en que estuviere destinado o del que dependa) ${ }^{102}$. También Nieto Martín es partidario de suprimir esta segunda modalidad, pues "resulta criticable el bajo grado de intensidad del conflicto [de intereses]. Pues basta, en el supuesto de conflicto real, con cualquier tipo de intervención y en los casos de conflicto potencial, con una mera cercanía espacial. Lo relevante es que el asunto haya pasado por el lugar de trabajo del funcionario. Esta estructura permite además que prácticamente cualquier funcionario público quede comprendido en el tipo penal"103.

Es cierto que existe mayor riesgo para el bien jurídico protegido cuanto mayor es la competencia del funcionario en el asunto, pero no descarto que también pueda existir un peligro relevante para la imparcialidad/objetividad en la segunda modalidad simplemente por la mera cercanía física. Pensemos en el siguiente ejemplo: Un administrativo que trabaja en el departamento de contratación del Ayuntamiento de Santiago de Com-

No obstante, si se establece una distinción entre el ilícito administrativo y el ilícito penal, reservando para el Derecho penal los casos más graves de ejercicio profesional o de asesoramiento incompatibles con la función pública (infra 9.4), dicho efecto simbólico no debería existir. Otra cosa es que para justificar la intervención penal en este terreno, hay que dotar de suficientes medios a la Administración de Justicia para perseguir y castigar estos delitos (supra 4), porque si no es así, se corre ese riesgo al que apunta García España.

102 Delgado Gil, Delitos cometidos por funcionarios públicos..., cit., p. 203.

103 Nieto Martín, en Eurodelitos de corrupción y fraude..., cit., p. 112. Según él, la intensidad del conflicto debe ser alta para que esté justificada la sanción penal, y es alta, siguiendo terminología del derecho norteamericano, cuando "el funcionario tenga una intervención personal y substancial en el asunto, lo que sirve para incrementar aún más el grado de peligro. No basta por tanto con tener una relación genérica con el asunto, ni mucho menos como ocurre con el 441 del CP español con que el asunto se decida en la misma oficina administrativa a la que pertenece el funcionario. En los casos de decisiones colegiadas ello implica, por ejemplo, que sólo existirá responsabilidad si el funcionario decide con su voto o tiene una participación muy activa en el proceso de deliberación" (p. 116). 
postela asesora periódicamente a una consultoría para que ésta prepare a sus clientes las ofertas más ventajosas, no para la Administración, sino para ellos (obviamente con posibilidades de éxito). A tal efecto, informa de cuáles son los próximos anuncios de licitación, los requisitos habituales en los pliegos de condiciones, la documentación complementaria que haya que aportar, etc. Dicha información la puede conseguir fácilmente, porque esos asuntos los lleva el compañero que tiene en la mesa de al lado. No obstante, esas concretas contrataciones él no las decide, ni las tiene que informar, ni tan siquiera las tramita, todo lo hace el compañero de al lado y no tiene nada más que estirar el brazo para conseguir los expedientes. Imaginemos que va a salir un anuncio relativo a la ejecución de una obra de remodelación con un presupuesto de $60.000 €$ y hay una Pyme interesada en su ejecución. Sin embargo, el citado administrativo le comunica a la consultoría que lo mejor es esperar, porque va a salir posteriormente otro contrato de $120.000 €$, de tal manera que si esa Pyme ejecutase el primer contrato, no podría optar al segundo de un mayor presupuesto, porque no tiene trabajadores suficientes para ejecutar los dos a la vez.

La intensidad en este caso puede haber sido baja, pero el conflicto de intereses ha sido grave. Lo que verdaderamente convierte a una actividad profesional o de asesoramiento incompatible con la función pública en punible es que se haga «bajo la dependencia o al servicio de» intereses privados.

\subsection{El núcleo del injusto penal: «bajo la dependencia o al servicio de» intereses privados}

En efecto, aquí radica la diferencia última entre una simple infracción administrativa del régimen de incompatibilidades y el delito del art. $441 \mathrm{CP}$, pues la expresión «bajo la dependencia o al servicio de entidades privadas o particulares» denota una peligrosidad mayor para el bien jurídico protegido que una simple infracción administrativa. Ello se produce cuando el funcionario, que desempeña una determinada función pública, pone a disposición de intereses privados su cargo o empleo 
público ${ }^{104}$. Utilizando terminología propia de la teoría de la imputación objetiva, esta característica es lo que imprime una referencia de sentido delictivo a la actividad profesional o del asesoramiento incompatible. No basta con que se produzca un incremento del riesgo para la imparcialidad/objetividad (mayor o menor según se trate de la modalidad de peligro concreto o de peligro hipotético), sino que es necesario que dicho incremento

104 En este sentido, véase la SAP Cáceres (Secc. 2a) 25/2009, de 7 de octubre, que absolvió al jefe de la unidad de sanciones de la Jefatura Provincial de Tráfico de Cáceres que reconoció que había algunos conocidos o amigos que en alguna ocasión le preguntaban sobre multas que les habían puesto por si se podía hacer algo y él, en algunas ocasiones, les aconsejaba que realizaran un escrito de alegaciones o un recurso de alzada, y en otras ocasiones les decía simplemente que pagaran la multa porque no se podía hacer nada. Para el Tribunal este actuar no constituye delito, porque tal proceder no "implica que se tenga una determinada subordinación o dependencia, como dice el precepto, de esa persona o entidad para la que se realiza el asesoramiento". "Depender de algo - dice- conlleva esa subordinación, ese hilo conductor, aún en asesoramiento accidental, que no necesariamente tiene que ser lucrativo, pero con algún tipo de vínculo dependiente, de subordinación, que en este supuesto no se ha puesto de relieve. Caso contrario estaríamos adelantando de una forma incomprensible la barrera punitiva que separa la infracción administrativa del delito penal". En el mismo sentido, entre otras, las SSAP Sevilla (Secc. 7 ) 62/2003, de 20 de noviembre; Valencia (Secc. $1^{\text {a) }}$ 252/2001, de 8 de octubre y el ATS de 2 de junio de 2008 (caso de la Presidenta del TC).

En algunas resoluciones, por el contrario, se omite el análisis de este elemento del tipo, como sucedió, por ejemplo, en la SAP Baleares (Secc. $1^{\mathrm{a}}$ ) $12 / 2000$, de 3 de febrero, la cual se contentó con que el acusado, siendo concejal y socio administrador de una correduría de seguros "tomó parte activa e intervino en un asunto de la Corporación en el que tenía interés personal, en tanto en cuanto era copartícipe de una empresa privada que estaba implicada en la negociación municipal"; o con un caso similar, la SAP Salamanca (Secc. $1^{\text {a }}$ ) 3/2006, de 24 de enero; o la SAP Baleares (Secc. 1 ${ }^{a}$ ) 26/2010, de 15 de marzo (confirmada por la STS 1189/2010, de 30 de diciembre), que se contentó con que "el acusado desarrolló actividades de asesoramiento en una empresa privada de seguridad, lo que está prohibido y es incompatible con la condición de guardia civil, por lo que cometió el delito que se le imputa"; o la SAP Salamanca (Secc. 1 ${ }^{\text {a) }}$ 32/2017, de 29 de mayo, que condenó a un veterinario perteneciente al Cuerpo Facultativo Superior, Escala Sanitaria (Veterinarios) por proceder a la vacunación y control de animales a título particular y cobrar por ello. 
del riesgo se produzca de forma jurídicamente desaprobada. La desaprobación jurídica de la actividad profesional o de asesoramiento girará entorno a la idea de la existencia de un sentido independiente de la actividad en cuestión, pero no con carácter general o de un modo abstracto (esto es, si es incompatible o no según la normativa administrativa), sino desde un punto de vista concreto o particular (en el caso concreto). Pues bien, en el caso concreto el carácter delictivo de esa actividad profesional o de asesoramiento se determinará por la finalidad a la que sirve, de tal modo que el funcionario realizará una actividad profesional o de asesoramiento punible cuando la misma tenga un valor para él mismo o para un tercero sólo desde el punto de vista de obtener o conceder una ventaja frente a los demás y además el funcionario lo sabe (o cuenta con ello y lo acepta, pues cabe el dolo eventual). Precisamente por eso lo hace, para beneficiar injustamente a un tercero o beneficiarse injustamente a sí mismo ${ }^{105}$. En este sentido el funcionario tendrá que asumir un interés de parte, que es lo que en última instancia pone en peligro la imparcialidad/objetividad. Paradigmáticas, en este sentido, han sido, por ejemplo, las SSTS 362/2014, de 25 de abril (caso ITV Cataluña)

105 Por eso entiendo, y en esto coincido con Delgado GiL, La Ley penal $\mathrm{n}^{\circ} 75$ (2010), p. 76, que en el caso del Presidente de la AP de Las Palmas hubo un asesoramiento típico, en contra de lo que decidió la STS 19/2010, de 25 de enero. El relato de los hechos es muy claro, pero creo que hay un dato decisivo en el cual no se ha insistido, y es cómo finaliza el antecedente de hecho $10^{\circ}$ : "Bueno, pero dile eso, que no se enrolle y que lo explique sencillo. Porque asi no predispone a la gente en contra, que se deje de rollos, ¿vale?" (cursiva añadida).

La SAP Cádiz (Secc. 1ª) 26/2011, de 14 de febrero, considera que la forma más habitual e inmediata de manifestarse esa dependencia o subordinación a los intereses privados es "mediante la percepción de una retribución económica", y "el concepto de «dependencia» no implica necesariamente aquí una dependencia orgánica, societaria, estructural o laboral".

La SAP Zaragoza (Secc. 6 $6^{\mathrm{a}}$ ) 1/2014, de 14 de abril [confirmada en cuanto a la condena por el art. 441 CP por la STSJ Aragón (Sala Civil y Penal) 4/2014, de 16 de septiembre], condenó al consejero del Área de Infraestructuras y concejal del Ayuntamiento de Zaragoza por negociar con el representante de una empresa la contratación de otra para el hormigonado de una obra a cambio de ofrecer dos obras a tercera persona. 
y 636/2012, de 13 de julio (caso operación Karlos), así como las SSAP Baleares (Secc. 2a) 394/2010, de 1 de diciembre (caso Andratx I) y 317/2014, de 17 de noviembre (caso Andratx II).

La STS 362/2014, de 25 de abril (caso ITV Cataluña) ${ }^{106}$, condenó al Presidente de la Secc. $5^{\text {a }}$ de la Sala de lo contencioso-administrativo del TSJ de Cataluña por el asesoramiento a personas y entidades interesadas en cuestiones relacionadas con la adjudicación y explotación de las estaciones de ITV, sobre asuntos que iban a ser resueltos, o que incluso lo estaban por el Tribunal que él presidía, resultando incluso designado ponente $\mathrm{y}$ actuando como tal en algunos recursos ${ }^{107}$.

106 Fruto de las escuchas telefónicas autorizadas por el Juzgado de Instrucción $\mathrm{n}^{\mathrm{o}} 9$ de Barcelona durante la tramitación de las Diligencias Previas 2028/2011, se elevaron dos piezas separadas (la $\mathrm{n}^{\circ} 1$ y la $^{\mathrm{o}} 3$ ) al TS por existir indicios racionales suficientes para imputar a dos personas aforadas, el Presidente de la Secc. $5^{\text {a }}$ y un Magistrado de la Secc. $1^{\text {a }}$, ambos de la Sala de lo contencioso-administrativo del TSJ de Cataluña, por sendos delitos de asesoramiento incompatible con la función pública del art. $441 \mathrm{CP}$. Por ATS de 18 de octubre de 2012 se declaró competente para la instrucción y enjuiciamiento de la pieza separada $\mathrm{n}^{\circ} 1$, que acabaría dando lugar a la condena por la STS 362/2014, de 25 de abril. Y por ATS de 2 de octubre de 2013 se declaró competente para la instrucción y enjuiciamiento de la pieza separada $n^{\circ} 3$, que daría lugar al ATS de 22 de octubre de 2014 que decretó el sobreseimiento libre por prescripción del delito.

107 A lo largo de los hechos probados existen numerosos ejemplos del asesoramiento que efectuó el Magistrado, que resume el f.j. $4^{\circ}$ del siguiente modo: "asesoró de manera permanente a CERTIO ITV, en asuntos en los que debía intervenir por razón de su cargo, pues aconsejó en la materia sobre la que versaban los recursos contenciosos administrativos que debían ser resueltos en el Tribunal que presidía, y ello a través de las acciones descritas con anterioridad: intercambió y comentó con ellos, de manera continuada, información sobre determinadas actuaciones judiciales relacionadas con dichos recursos; envió un modelo al que ajustar la presentación de uno de sus recursos; habló con su abogado sobre otro de ellos, en el que pedía la adopción de unas medidas cautelares, dándole su conformidad al mismo; y promovió reuniones o encuentros con las letradas de la Generalidad de Cataluña, la Administración contra la que CERTIO litigaba, con el resultado y finalidad ya descritos". Y a continuación hace la siguiente consideración: "La actuación del acusado, valorada en su conjunto, y teniendo en cuenta, su prolongación en el tiempo, su naturaleza y los actos en los que se materializó, comprometieron sin duda su imparcialidad y objetividad, pues estaba destinada a favorecer los intereses de una de las partes en litigio, CERTIO 
La STS 636/2012, de 13 de julio (caso operación Karlos), que confirma la SAP Cádiz (Secc. $3^{\text {a }}$ ) 219/2011, de 8 de julio, juzgó unos hechos que tuvieron amplia repercusión mediática por verse involucrada la mujer de un famoso torero. Se condenó por este delito, además de por falsedades documentales y estafa, a un inspector médico de la Unidad de Valoración Médica de Incapacidades de la Junta de Andalucía, adscrito a la Delegación Provincial de Salud de Cádiz, que junto a otras personas diseñaron una trama para la consecución ilícita de pensiones de incapacidad engañando a la Administración competente para reconocerla desde dentro, desde su propio organigrama, todo ello movido por un fin lucrativo ${ }^{108}$.

ITV, la cual, precisamente por ello, contó con el apoyo del Presidente del Tribunal que debía conocer de los recursos en los que intervenía, con el que consultaba el devenir de estos recursos" (cursiva añadida).

En el ATS de 23 de abril de 2013, por el que se ordena continuar la tramitación de la causa contra el aforado, se decía: "En la misma línea, no solo expresó su conformidad con esa concreta actuación, sino que en varias ocasiones orientó a los citados [interesados] acerca de la posible solución de las cuestiones existentes exponiendo su punto de vista sobre el particular, lo que permitía a éstos adoptar con antelación las decisiones que tuvieran por convenientes" (f.j. $2^{\circ}$, cursiva añadida).

108 En el f.j. $10^{\circ}$ de la SAP Cádiz (Secc. 3a) 219/2011, de 8 de julio, se transcriben algunas de las actuaciones que demuestran el carácter claramente delictivo del asesoramiento. A título ejemplificativo, cabe mencionar que el inspector médico indica en una conversación que con ese informe no se podría conseguir más que una total, pero que hablará con el autor del mismo para que "me pone dos o tres frases que yo me sé, podemos conseguir la absoluta, ¿vale?"; o en otra conversación indica que "es tan fácil como decir eso, que no, que la columna la tiene jodida, que a él le duele mucho y que cada vez que se agache o levante un peso se tiene que llevar cuatro días sin moverse"... "este hombre tiene que decir que está tomando Fluoxetina"... "veinte miligramos. Una pastilla por las mañanas"...; además el inspector recopilaba la documentación necesaria para la incoación del expediente y se encargaba de prepararlo adecuadamente para asegurar en la mayor medida el resultado deseado.

La STS 636/2012, de 13 de julio, no desarrolla pormenorizadamente la fundamentación de la condena en este punto, pues entiende que no precisa invocar muchos pasajes para estimar la validez la condena por este delito, pero sí que señala que algunas de las actividades ilícitas que llevaba a cabo el acusado consistían en estudiar el caso y preparar el recurso, o incluso redactarlo personalmente, contra las decisiones que no eran del agrado del cliente porque no le concedían la invalidez que quería (f.j. $7^{\circ} .4$ ). 
La SAP Baleares (Secc. 2a) 394/2010, de 1 de diciembre (caso Andratx I), que condenó al Director General de Ordenación del Territorio del Govern Balear, que a través de una empresa intermediaria creada por él, asesoró a una sociedad anónima en una demanda de reclamación de responsabilidad patrimonial que presentó contra la Comunidad Autónoma por pérdida del aprovechamiento urbanístico de una parcela de su propiedad en el municipio de Andratx, y luego también en un recurso contencioso-administrativo ante el TSJ y en un recurso de casación ante el TS. El Director General, que antes había sido Jefe del Área de Urbanismo del Ayuntamiento de Andratx, cobró al menos 7.000.000 pesetas por 4 informes (sobre el coste económico de la obra urbanizadora; sobre el valor medio de venta del metro cuadrado construido; sobre la cuantificación de la total indemnización; y sobre los gastos necesarios efectuados para la obra urbanizadora ejecutada) y siguió prestando labores de consultoría y asesoramiento para la sociedad demandante y para el despacho de abogados que había contratado ${ }^{109}$.

Y la SAP Baleares (Secc. 2a) 317/2014, de 17 de noviembre (caso Andratx II), que condenó al Alcalde del Ayuntamiento de Andratx, que también era el Concejal delegado en materias de urbanismo, por haber votado en diversas ocasiones la concesión de licencias de construcción para una sociedad en cual participaba junto a otro funcionario y un arquitecto y su hijo. Dicha sociedad se constituyó inicialmente por estos dos últimos, y en el mismo día se transmitió al alcalde y al otro funcionario un tercio de las participaciones sociales a cada uno, para que así no apareciesen en el registro mercantil como socios constituyentes ${ }^{110}$.

109 En el f.j. $2^{\circ}$ se puede leer que el acusado, siendo ya Director General de Ordenación del Territorio del Gobierno Autonómico, seguía ocupándose personalmente de cuantas cuestiones se vinculaban con el urbanismo en el municipio de Andratx... intervención o participación que debe ponerse en contacto con el encargo... para que las respuestas que el ayuntamiento dé a la Sala de lo Contencioso se ajusten o estén a tono -expresión entrecomillada- con la realidad de lo sucedido.

110 En el segundo de los hechos declarados probados la SJP n ${ }^{\circ} 4$ de Palma de Mallorca 178/2013, de 22 de mayo, que confirma la Secc. $2^{\text {a }}$ de la AP, se dice que "los tres idearon crear varias sociedades privadas para adquirir solares ubicados en Andratx, y posteriormente promover y construir inmuebles destinados a la venta de pisos a terceros, y aprovechando que [el Alcalde] 
Esa finalidad a la que sirve la conducta del funcionario, esa ventaja o beneficio que pretende conceder u obtener, no tiene por qué ser de naturaleza económica. Es cierto que la mayoría de los casos de delitos de actividades incompatibles con la función pública tienen que ver con la obtención de beneficios económicos (propios o ajenos) y que los demás casos son excepcionales o una "zona marginal" "111. Sin embargo, que sean infrecuentes no quiere decir que sean irrelevantes. Por ello, en mi opinión, no puedo compartir plenamente el planteamiento que hace GARCíA ESPAÑA a la hora de distinguir entre el ilícito administrativo y el ilícito penal en este terreno ${ }^{112}$. Según esta autora, éste se caracterizaría, aparte de por el prevalimiento del cargo, por un mayor desvalor de resultado, que ella cifra en un perjuicio patrimonial a tercero o a la propia Administración y también porque esta conducta debe estar animada por el lucro.

formaba parte de la Junta de gobierno de dicho Ayuntamiento, que concedía las licencias de obra, además de ser el concejal delegado de urbanismo, y que [el otro funcionario] era el celador de las obras en dicha Administración local, conseguir tramitar con mucha celeridad las licencias de obras y en las certificaciones de final de obra relativas a dichas promociones inmobiliarias en las que estaban interesados privadamente, sin que el Alcalde ni el celador se abstuvieran de intervenir en ninguno de los correspondientes expedientes administrativos" (cursiva añadida).

Cabe recordar también aquí el supuesto de hecho de la STS 1048/1997, de 18 de julio (citada en n. 13).

111 SANCINETti, $A D P C P$ 1986, p. 882.

112 Esta autora considera que el bien jurídico protegido en este delito es la función pública, que por definición es normativa, dinámica e instrumental, y en el caso de la función administrativa lo concreta en "el conjunto de actuaciones y resolución que, ordenadas hacia el interés general, deben ser adoptadas con imparcialidad y con plena sujeción al principio de legalidad por las autoridades o funcionarios públicos en el ámbito de sus respectivas competencias" [García España, JpD 48 (2003), p. 54]. Discrepa de poder elevar a la categoría de bien jurídico protegido los principios rectores que delimitan la función social de la Administración pública. Para ella los deberes del cargo no son el bien jurídico protegido pero hay que tenerlos en cuenta, pues a través del correcto ejercicio de todos esos deberes tendentes a la consecución del interés general es como se logra el ejercicio de la función pública. En definitiva, concreta el bien jurídico en el correcto ejercicio de todos los deberes del cargo tendentes a la consecución del interés general 
Por lo que al prevalimiento del cargo se refiere, conviene aclarar que más que ante un prevalimiento estamos ante un abuso en el cargo, pues lo relevante no es que el carácter público del sujeto activo haga más fácil y cómoda la realización de la actividad profesional o de asesoramiento ${ }^{113}$, que es lo que sería un prevalimiento, sino que lo importante es que estamos ante lo que la rúbrica del Cap. IX del Tít. XIX califica como «actividades prohibidas» $\mathrm{o}$ «abusos» ${ }^{114}$. Hay que tener en cuenta que el art.

al que está orientado el ejercicio de la función pública. Se precisa que todas las actuaciones sucesivas y concatenadas que conforman el proceder administrativo se dirijan hacia una misma dirección: el interés general, que se alcanzará cuando los garantes de la función pública realicen sus actividades conforme a sus deberes del cargo. Según esta autora, dos tipos de afección puede sufrir este bien jurídico: por un lado, impedir el inicio u obstaculizar este proceder; y por otro, desviarlo o utilizarlo para intereses que no son los generales. Según ella, el art. $439 \mathrm{CP}$ puede incluirse en la segunda modalidad lesiva, pero en el art. $441 \mathrm{CP}$ se hace difícil ver la existencia de un injusto penal (p. 55).

113 Crespo Barquero, en Serrano Butragueño (coord.): Código Penal II, p. 2442 , reconoce expresamente que "la exigencia de esa relación con la esfera de actividad del autor del delito supone la incorporación al tipo del prevalimiento del cargo". Y parece que limita el art. 441 CP exclusivamente a este tipo de supuestos Rivera Hernández, J.M.: «Los delitos de cohecho, tráfico de influencias, negociaciones y actividades prohibidas a los funcionarios públicos y abusos en el ejercicio de la función», en Revista Aragonesa de Administración Pública ${ }^{\circ} 11$ (1997), 424, al considerar que son punibles sólo aquellas infracciones de normas sobre incompatibilidades que "pon[gan] el cargo público al servicio del interés privado, utilizando el cargo público para un mejor ejercicio profesional particular, desarrollando actividades públicas y particulares unidas entre sí por conexidad funcional dependiente”. También PiÑol Rodríguez, J.R., en Suárez-Mira Rodríguez (coord.), Manual... II, cit., p. 549, ya que este delito "constituye un medio de obtención de «clientela» para su profesión en razón de las funciones que desempeña".

114 Por ejemplo, Morillas Cueva, Sistema de Derecho penal, $2^{\mathrm{a}}$ ed., cit., p. 1192, habla de "abusos de compatibilidades, que conculcan el buen funcionamiento de la Administración Pública"; o Muñoz Conde, Parte Especial, cit., p. 895, dice que "lo fundamental es, pues, la idea del abuso de las funciones públicas propias del funcionario que actúa dentro de los límites de su función o mando; es decir, que la acción se desarrolle en los ámbitos en los que la autoridad o funcionario deban intervenir por razón de su cargo". 
198 CP/1944, antecedente del actual art. 441 CP, expresamente exigía dicho prevalimiento del cargo y ahora no se recoge en el tipo. Es más, un autor tan destacado como CóRDOBa RodA, decía que aquel requisito típico "conduc[ía] a un insatisfactorio estrechamiento del ámbito de lo delictivo" 115 , pues el prevalimiento del cargo "deb[ía] hallar su manifestación en la práctica de dichas acciones", es decir, de la actividad profesional e intervención en empresas o asociaciones, y no cuando "dicta en el desempeño de sus funciones resoluciones injustas que favorecen los intereses que él en su actividad profesional defiende" $" 116$.

En cuanto a la naturaleza económica o patrimonial de este delito, considero que en muchos delitos de funcionarios,

Por este motivo, la SAP Sevilla (Secc. $1^{\text {a }}$ ) 169/2005, de 16 de marzo (confirmada en este punto por la STS 1259/2006, de 14 de diciembre), absolvió del delito del art. $441 \mathrm{CP}$ a un guardia civil que realizó una inspección a una residencia de ancianos con la finalidad de presionar, en favor de un amigo suyo, para que la dueña pagase la deuda que tenía con éste.

115 Córdoba Roda, J.: Comentarios al Código Penal, t. III (Artículos 120-340 bis c), Barcelona, 1972, p. 376.

116 Córdoba Roda, Comentarios III, cit., p. 375. Y ponía el siguiente ejemplo: "funcionario de un organismo público y abogado en ejercicio que asesora en su despacho profesional a quienes tienen pretensiones pendientes de la resolución o intervención de aquél, que acuden al indicado despacho por sugerencia del propio sujeto. No incurre, en cambio, en el tipo del artículo 198 el propio funcionario y letrado que, al despachar los asuntos propios de la función pública que desempeña, favorece a los clientes de su ejercicio profesional privado, que han solicitado su asesoramiento jurídico por razones que nada tienen que ver con su esfera de atribuciones oficiales". Y concluye: "Una tal exigencia debe ser estrictamente observada por venir impuesta por la recta interpretación del precepto legal".

Ahora, en cambio, no lo exige, también por una recta interpretación del tipo. Véase, Córdoba Roda, en Córdoba Roda/García Arán (dirs.): Comentarios..., p. 2107, aunque señala que hay cierta Jurisprudencia que entiende que sí es necesario dicho requisito. La STS 372/1998, de 9 de diciembre, señala que el art. $441 \mathrm{CP}$ es aplicable "a los funcionarios y autoridades que reali[cen] actividades directamente relacionadas con la esfera de sus atribuciones oficiales, y en el ejercicio de éstas se aprovechasen ilícitamente de su cargo, es decir utilizasen la preeminencia que su cargo público les proporcionaba para obtener abusivas ventajas en su actividad privada" (con cita de las SSTS de 18 de julio de 1997 y de 14 de octubre de 1997). 
incluido éste, hay que tener una visión más amplia de la que nos proporciona la corrupción. No todo delito contra la Administración pública tiene que ver con la corrupción ${ }^{117}$. Ni la obtención de un beneficio económico, que es a lo que se asocia la corrupción, tiene por qué ser el dato decisivo a la hora de justificar la intervención penal en este terreno ${ }^{118}$. Lo determinante aquí es que el interés particular (económico o no) por el que actúa el funcionario sea distinto al de la Administración ${ }^{119} \mathrm{y}$ es aquí donde se produciría, a mi modo de ver, esa segunda modalidad lesiva o de peligro para el bien jurídico protegido de la que ha-

117 El delito de malversación, por ejemplo, es un delito muy característico del fenómeno de la corrupción. Sin embargo, no hay que verlo exclusivamente desde ese ángulo. En el CP/1944 la malversación no exigía ánimo de lucro. El CP/1995 lo introdujo, probablemente por la coyuntura en que se elaboró, pero la reforma de 2015 ha vuelto a prescindir de ese elemento subjetivo del injusto al configurar dicho delito como una administración desleal, que no tiene por qué ir dirigida a la obtención de un lucro, aunque sí debe ocasionar un perjuicio económico. Véase, entre otros, SAINZ-CANTERo CAPARRós, J.E.: "La reforma de los delitos contra la administración pública", en L. Morillas Cueva (dir.): Estudios sobre el Código Penal reformado. (Leyes Orgánicas 1/2015 y 2/2015), Madrid, 2015, p. 839.

118 En contra, NiETo MarTín, en Eurodelitos de corrupción y fraude..., cit., p. 115 , pues considera que los conflictos de intereses punibles deben ser "exclusivamente aquellos de tipo patrimonial, de modo semejante al § 208 USC". Polaino Navarrete, Lecciones II, p. 361, entiende también que "la descripción positiva no especifica el carácter económico de la ilegal participación del funcionario en actividad profesional privada, pero ha de entenderse implícita en el comportamiento del funcionario", y si no tuviese contenido económico alguno "podrá tener relevancia en su caso en otras figuras delictivas, como la de prevaricación, o remitir a la esfera de los ilícitos administrativos".

119 En este sentido, la SAP Barcelona (Secc. $5^{\text {a }}$ ) de 23 de febrero de 2000, considera que "dicho Capítulo contiene un conjunto heterogéneo de delitos cuyo denominador común debe cifrarse en el abuso del cargo con la finalidad, directa o indirecta, de obtener un beneficio económico o de otro tipo, es decir que tales conductas en él incriminadas se caracterizan por suponer una instrumentalización de las funciones públicas para la obtención de fines distintos o contrarios a los generales, si bien la mayor parte de los delitos que forman parte de él no requieren la constatación de una efectiva lesión del correcto funcionamiento de la Administración por cuanto que se configuran como tipos de peligro (abstracto o concreto)". 
bla García España de desviación del interés general ${ }^{120}$. Puede haber perfectamente actuaciones interesadas no valuables económicamente, como por ejemplo, las relativas a la concesión de una licencia de armas, o para la tenencia de un perro peligroso, o el saltarse una lista de espera para operarse, que afectan gravemente al correcto funcionamiento de la función pública y no entrañan desde el punto de vista económico ningún beneficio o perjuicio.

\section{Tipo subjetivo}

El art. $441 \mathrm{CP}$ es un delito exclusivamente doloso, admitiéndose el dolo eventual ${ }^{121}$, sin que esté prevista su comisión imprudente. No se exige expresamente ningún elemento subjetivo del injusto ${ }^{122}$. No obstante, una parte de la doctrina y de la

120 SANCINETTI, $A D P C P 1986$, p. 880, dice que "es indudable que la actuación parcial de los órganos administrativos, que define el ámbito de lo injusto de este delito, no se incrementa en modo alguno por el grado de beneficio que el funcionario pueda obtener, ni por el eventual perjuicio administrativo, sino que deviene definitivamente configurada en cuanto el funcionario realiza un acto desviado por la prosecución de un interés espurio".

121 Así, Mir Puig, C.: Los delitos contra la Administración pública ..., cit., p. 368. García España, $J p D$ n $^{\circ} 48$ (2003), p. 61, lo admite pero de modo muy excepcional. También lo admite la STS $765 / 2014$, de 4 de noviembre, pues se "convierte en dolosa - dice- la conducta de quien asume la posibilidad de que el asunto en el que asesora o actúa sea más que probable que se acabe decidiendo por la oficina o centro directivo al que pertenece el funcionario".

122 Así, entre otros, Mir PUIG, C.: Los delitos contra la Administración pública ..., cit., p. 368; MiR PUIG, S.: $C D J \mathrm{n}^{\circ} 30$ (1996), p. 328. Este autor, bajo la vigencia del anterior $\mathrm{CP}$, daba una visión más lucrativa a los delitos de negociaciones prohibidas: Mir PuIG, S.: NEJ t. XVII (1982), p. 203. Tampoco aprecian elemento subjetivo del injusto, entre otros, Crespo BARquero, en Serrano Butragueño (coord.): Código Penal II, p. 2442; MuÑoz Cuesta, RJA no 19 (2008); Polaino Navarrete, Lecciones II, p. 362.

Tampoco lo exigen, entre otras, las SSTS 92/1999, de 1 de febrero; 484/2008, de 11 de julio; 1189/2010, de 30 de diciembre; 765/2014, de 4 de noviembre; 673/2016, de 21 de julio; SSAP Barcelona (Secc. $5^{\text {a }}$ ) de 23 de febrero de 2000; (Secc. 21ª) 718/2011, de 23 de mayo; Cáceres (Secc. $1^{\text {a }}$ ) 26/2011, de 14 de febrero; Sevilla (Secc. $7^{\mathrm{a}}$ ) 62/2003, de 20 de noviembre; AAP Ciudad Real (Secc. 1ª) 94/2008, de 5 de junio. 
jurisprudencia consideran que es consustancial a este precepto el ánimo de lucro y lo exigen ${ }^{123}$. Sin embargo, lo cierto es que el art. $441 \mathrm{CP}$ no lo contempla expresamente, a diferencia de lo que hacían sus antecedentes: los arts. $221 \mathrm{CP} / 1932$ y $198 \mathrm{CP} / 1944^{124}$. Sí es verdad que es inherente a la realización de una actividad profesional la intención de obtener un beneficio económico. Incluso lo normal será que esa intención esté presente también en un asesoramiento de carácter permanente. Sin embargo, no tiene por qué ser así en uno accidental.

La jurisprudencia es muy reacia a apreciar el error ${ }^{125}$, pues considera que es evidente que los funcionarios conocen la existencia de la incompatibilidad, y si no la conocen, en muchas ocasiones hay quien se la recuerda ${ }^{126}$. Como dice la STS

123 Por ejemplo, Delgado Gil, Delitos cometidos por funcionarios públicos..., cit., p. 214; García EspaÑa, $J p D$ n $^{\circ} 48$ (2003), p. 62, que lo deduce de la expresión «bajo la dependencia o al servicio de entidades privadas o de particulares»; Garcés CARbonell, Foro FICP n 2013-2, p. 304.

124 Por cierto, que no estaba claro si el art. 198 CP/1944 refería el ánimo de lucro a una o a las dos conductas que incriminaba. Cuello Calón, E.: Derecho pe-

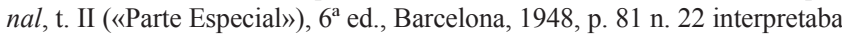
que el "móvil de lucro" sólo se refería a una de las conductas que contemplaba el art. $198 \mathrm{CP} / 1944$. En cambio, respecto del art. $221 \mathrm{CP} / 1932$ decía que "de la colocación de las comas en esta redacción resulta que el móvil de lucro es elemento integrante del delito para ambos supuestos... Por el contrario, dada la colocación de las mismas en el texto vigente, el móvil de lucro resulta sólo elemento integrante de la segunda modalidad de la infracción, en la intervención en empresas o asociaciones". Por eso se preguntaba si "el cambio de comas, y como consecuencia el diferente sentido del precepto ¿ha sido meditado e intencional o motivado por puro descuido?".

Por su parte, Córdoba Roda, Comentarios III, cit., p. 375, decía que "pese a lo poco afortunado de la redacción, parece claro que el móvil de lucro no debe concurrir en las empresas o asociaciones, sino en la acción de intervenir".

125 La SAP Pontevedra (Secc. 3 ${ }^{\text {a }}$ ) 96/2001, de 20 de diciembre, lo apreció, pues no se podía considerar probado que el arquitecto municipal conociese que estuviese actuando (otorgar certificación de obra como profesional privado, para lo que tenía concedida la compatibilidad fuera del término municipal) en un asunto en el que ya había intervenido (hace 5 años y la obra finalmente ejecutada era distinta de la que la licencia permitía).

126 Por ejemplo, en la SAP Baleares (Secc. $2^{\mathrm{a}}$ ) 317/2014, de 17 de noviembre (caso Andratx II) la defensa del Alcalde alegó que el Secretario no le advir- 
1048/1997, de 18 de julio, "es evidente que la noción de que no puede obtenerse un beneficio privado de un cargo público ni intervenir en decisiones administrativas sobre cuestiones en que se tiene un interés directo se encuentra arraigada en la sociedad y pertenece al acervo cultural común, por lo que la generalidad de las gentes rechazan y reprochan tal tipo de conductas. Debe estimarse, en consecuencia, que el recurrente no sólo no podía ser ajeno a dicho sentir general, sino que, por el desempeño de su cargo, debía tener un superior conocimiento de sus deberes e incompatibilidades, y concretamente de la incompatibilidad entre su actividad privada como titular y asesor de empresas constructoras y la participación en la adopción de acuerdos administrativos que afectaban directamente a las solicitudes formuladas por las referidas empresas" (también la STS 1269/1997, de 14 de octubre).

\section{Iter criminis}

Puesto que se trata de un delito de mera actividad (supra 6), el delito se consuma con la realización de la actividad profesional o del asesoramiento, sin que se requiera que se produzca un resultado material externo perceptible. Por tanto, no se exige para la consumación que se produzca incidencia de modo real en el ejercicio de las funciones públicas ${ }^{127}$, ni tampoco "es preciso

tió del contenido de la votación, como sí ocurrió en otras ocasiones, pero dado que la incompatibilidad era evidente, "no se puede sostener que el acusado ignorara que era contrario al correcto desempeño de su función votar como alcalde en las licencias de obras sobre solares propiedad de la empresa en la que participaba y de la que dependían futuros beneficios económicos". En igual sentido, véanse las SSAP Madrid (Secc. 6a) 348/1998, de 23 de junio; Pontevedra (Secc. $3^{\text {a }}$ ) 43/2002, de 9 de octubre; Valencia (Secc. $1^{\text {a }}$ ) 252/2001, de 8 de octubre; SJP n 4 Pamplona 251/2009, de 4 de junio.

127 Crespo Barquero, en Serrano Butragueño (coord.): Código Penal II, p. 2440. También MuÑoz CuESTA, RJA n 19 (2008), quien afirma que "si tal incidencia se llegase a concretar nos hallaríamos ante un delito de prevaricación en la mayoría de los casos..., o en otro ilícito penal de los cometidos por los funcionarios públicos". Del mismo modo, la STS 765/2014, de 4 de noviembre. 
que la realización de la actividad sea completa o total para que se perfeccione el delito"128. Por ejemplo, cuando se estuviere elaborando un proyecto, aunque no se haya finalizado, ya se habría consumado el delito.

Dada esta naturaleza, en principio, los supuestos de ejecución incompleta serían poco verosímiles, sin embargo, no hay por qué descartarlos del todo ${ }^{129}$. Ahora bien, desde un punto de vista político-criminal no se deberían incriminar las formas imperfectas de ejecución, y menos aún, los actos preparatorios. Sin embargo, la LO 1/2015, de 30 de marzo, ha dado nueva redacción al art. $445 \mathrm{CP}$, mediante el cual se consideran punibles los actos preparatorios de conspiración, proposición o provocación (arts. 17 y $18 \mathrm{CP}$ ) para cometer cualquiera de los delitos contra la Administración pública, incluido el de realizar una actividad profesional o de asesoramiento incompatible con la función pública del art. $441 \mathrm{CP}$. Siendo éste como es un delito de peligro, incluso de peligro hipotético, el cual supone ya un considerable adelantamiento de las barreras de la intervención penal, parece muy criticable que se anticipe aun más dicha intervención castigando esos actos preparatorios. Ello puede resultar hasta criminógeno. El legislador de 2015 tendría que haber seleccionado mejor en qué delitos del Título XIX puede ser conveniente la incriminación de esos actos preparatorios. Además, esta dispo-

128 Catalán Sender, $A P \mathrm{n}^{\circ} 29$ (1998), p. 534.

129 Así, García España, $J p D$ n $^{\circ} 48$ (2003), p. 63, pone dos ejemplos de formas imperfectas de ejecución: una tentativa acabada, en el caso de un funcionario que, de forma ocasional, elabora un informe a través del cual lleva a cabo el asesoramiento sobre un determinado asunto de su competencia a un particular, informe que finalmente no llega a manos de éste por causas ajenas a la voluntad del funcionario; y una tentativa inacabada, cuando una entidad privada contrata formalmente a una autoridad o funcionario público para que le asesore o actúe profesionalmente para ella con carácter permanente, pero que finalmente, por causas ajenas a la autoridad o funcionario, por ejemplo una baja por enfermedad, la actividad profesional o de asesoramiento no llega a realizarse". No obstante, en este segundo supuesto puede ser discutible que se haya superado la mera fase preparatoria (conspiración) y haya dado ya comienzo la ejecución del delito. 
sición va a traer problemas de delimitación entre lo que serían esos simples actos preparatorios y el comienzo ya de la fase de ejecución ${ }^{130}$.

\section{Autoría y participación}

La conducta típica ( «realizar una actividad profesional o de asesoramiento»), en principio, sólo admitiría la autoría directa unipersonal. Sin embargo, se considera que la cláusula «por sí o por persona interpuesta» ${ }^{131}$, permite abarcar también los supuestos de autoría mediata ${ }^{132}$ en los que el funcionario no realiza por sí mismo la actividad profesional o de asesoramiento, sino que se sirve de un particular para llevarla a cabo que actúe también dolosamente (instrumento doloso no cualificado). En este sentido, VÁzquez-Portomeñe Seijas ha reconocido expresamente la utilidad de incisos de este género que se contienen en los delitos de funcionarios, y en particular, respecto del delito del art. 441 señala que "en la incorporación legal de la persona interpuesta a la dinámica comisiva del delito de realización de actividades incompatibles con la función toma cuerpo, en este sentido, la más genuina de las soluciones de técnica legislativa a los problemas de incriminación de la autoría mediata con instrumento doloso no cualificado, al prevenir la burla del artículo 441 mediante la intercalación de testaferros o de personas jurídicas

130 Valeije Álvarez, I.: «Disposición común a los capítulos anteriores (art. 445)», en J.L. González Cussac (dir.): Comentarios a la reforma del Código Penal de 2015, Valencia, 2015, p. 1224.

131 Córdoba Roda, en Córdoba Roda/García Arán (dirs.), Comentarios..., p. 2106, señala que en el marco del CP/1973 era cuestión debatida la de si el ejercicio de la respectiva profesión exigía una inmediación del sujeto o admitía la práctica por personas interpuestas. Él entendía que la "práctica de la profesión por personas interpuestas, no [podía] dar lugar a la estimación del presente delito", porque "el artículo 198 al describir la primera modalidad prescind[ía] de la referencia a la actuación indirecta, que incluí[ía] en cambio al regular la segunda [intervención en empresas o asociaciones]" (Córdoba Roda, Comentarios III, cit., p. 374).

132 Así, entre otros, García España, JpD no 48 (2003), p. 64; Morales Prats/ Rodríguez Puerta, en Quintero Olivares (dir.): Comentarios..., cit., p. 1802. 
como autores formales de la actuación profesional o de asesoramiento de que se trate" 133 .

Catalán Sender se cuestiona si la locución «persona interpuesta» comprende sólo los supuestos en que la actividad la realiza el funcionario, pero la firma un testaferro para eludir el sistema de incompatibilidades, o si también abarca los casos en que la actividad no la realiza el funcionario, sino un tercero que forma parte de una sociedad o de otra persona jurídica a la que también pertenece aquél y luego dicho funcionario informa o resuelve. Según él, y comparto su opinión, "en base al principio de legalidad que rige en Derecho Penal sólo la primera conducta está contemplada en este tipo penal, pues según la literalidad del precepto ha de ser el funcionario o autoridad que va a informar o resolver quien realice la actividad o asesoramiento y no otra persona y mucho menos si no es funcionaria, por más que pertenezca todos ellos a una sociedad" ${ }^{134}$, aunque él opina que de lege ferenda debiera ser punible.

Yo no comparto esta propuesta, por lo siguiente. Según llama la atención SANCINETTI, el uso de la persona interpuesta puede darse de dos formas diferentes ${ }^{135}$ : bien como intermediación en la actuación, como una especie de cláusula de autoría mediata con instrumento doloso no cualificado, que es lo que figura en el art. $441 \mathrm{CP}$, o bien como intermediación en el interés, que es lo que creo a lo que estaría aludiendo Catalán SEnder y no parece que esta cláusula incluya eso, dada la proximidad sintáctica con el verbo «realizare» y no con «al servicio de». Pero es que, a mayor abundamiento, tales supuestos no serían punibles por tratarse, en el fondo, de un delito imposible por ausencia de un sujeto idóneo ${ }^{136}$ con arreglo al tipo del art. 441

133 VÁzquez-Portomeñe Seijas, F.: Los delitos contra la Administración pública. Teoría general, Madrid, 2003, p. 421.

134 Catalán Sender, AP 29 (1998), p. 532.

135 SANCINETTI, ADPCP 1986, p. 883.

136 VÁzquez-Portomeñe Seijas, F.: Los delitos contra la Administración pública, cit., p. 441 ss. 
CP. Y esta supuesta laguna de punibilidad no podría ser colmada, como ha sugerido algún autor ${ }^{137}$, por lo dispuesto en el art. $31 \mathrm{CP}$, ya que este precepto no comporta un concepto unitario de autor en los delitos especiales, sino que el extraneus cuya actuación quedase comprendida por el art. $31 \mathrm{CP}$ responderá como autor del delito especial si actúa con los demás requisitos definidores de la autoría ${ }^{138}$, en particular la infracción de los deberes inherentes al cargo. Por lo tanto, toda persona que intervenga de algún modo en la ejecución del delito y no reúna las cualidades especiales para ser autor únicamente podrá ser considerado, todo lo más, partícipe. Así, la persona interpuesta de que se sirve el funcionario para realizar la actividad profesional o asesoramiento incompatible puede responder como cooperador necesario ${ }^{139}$ y quien solicita el asesoramiento o la actividad profesional podrá ser considerado inductor, entrando en juego en ambos casos el art. 65.3 CP.

\section{Concursos}

El delito de actividad profesional o de asesoramiento incompatibles puede consistir en un solo acto o en varios, lo

137 Crespo Barquero, en Serrano Butragueño (coord.), Código Penal II, cit., p. 2440 y 2441 . En contra, García EsPaÑa, $J p D$ n $^{\circ} 48$ (2003), p. 64, para quien "más difícil resulta alcanzar supuestos que tengan cabida en el artículo 31 del Código penal".

138 Por todos, Díaz y García Conlledo, M.: La autoría en Derecho Penal, Barcelona, 1991, p. 228.

139 Por ejemplo, la STS 224/1998, de 30 de noviembre; SAP Barcelona (Secc. $21^{\text {a }}$ ) 718/2011, de 23 de mayo; o la SJP no 4 Pamplona 251/2009, de 4 de junio. La STS 119/2012, de 15 de marzo, no apreció cooperación necesaria en el Alcalde que no impidió que un concejal realizase actividades privadas incompatibles con la función pública, porque no se podía aplicar el art. 11 $\mathrm{CP}$, ya que el art. $441 \mathrm{CP}$ no es un delito de resultado y además no había posición de garante: "no puede predicarse un deber específico del Alcalde dirigido a evitar actividades privadas" del concejal. Por el contrario, en Voto Particular a esta STS, los magistrados que lo emitieron consideraron que la conducta del Alcalde sí era constitutiva de cooperación necesaria, pues su actuación no debió valorarse como una omisión, sino como una acción. 
cual pudiera dar lugar a diversos problemas concursales homogéneos.

Posada Maya, a propósito de un caso sucedido en Colombia, examina detenidamente esta problemática concursal que plantea el delito del art. 421 CP colombiano, el cual castiga al «servidor público que ilegalmente represente, litigue, gestione o asesore en asunto judicial administrativo o policivo» ${ }^{140}$. Las posibilidades que se podían plantear en aquel caso eran si había unidad de acción y de delito, como alegaba la defensa, si estamos en presencia de un delito continuado, o si por el contrario, como finalmente decidió la Corte Suprema de Justicia, se trataba de un concurso real de delitos.

El caso era el siguiente: L.S.V., en calidad de oficial mayor de la secretaría del Tribunal Superior de Distrito Judicial de Ibagué (Tolima), realizaba, por conducto del abogado J.A.M.A., actividades de asesoría, litigio, elaboración de demandas y memoriales de distinta naturaleza e ilustraba en distintos procesos judiciales acerca de las pruebas que las partes debían solicitar. Por realizar tal actividad, el funcionario público cobrara el $10 \%$ de los honorarios profesionales que obtenía el abogado en cada actuación judicial. Concretamente se le condenó por tres delitos constitutivos de asesoramiento ilegal respecto del abogado J.A.M.A., a quien ayudó en la confección de una acción popular contra el municipio de Ibagué y cobró \$300.000; le redactó la demanda en el proceso "Yara Bambiela", cobrando \$ 1.500.000; y le confeccionó la demanda en el proceso de N.F., caso en el cual pactó como contraprestación un porcentaje de los honorarios.

Posada MAYA le da la razón a la Corte Suprema, primero, porque no hay unidad de acción, y segundo, porque no hay delito continuado. "Habría una conducta única -dice- en el evento [que no fue el caso] de presentarse un único asesoramiento o gestión ilegal por parte del servidor público que favorezca a particulares (presentar un documento, absolver una consulta, realizar un trámite único, etc.)" (p. 11). También "se podría

140 Posada Maya, R.: "Delito único, delito continuado y concurso de delitos. A propósito de la conducta punible de asesoramiento ilegal", Revista General de Derecho Penal no 26 (2016), p. 1-33. 
advertir una conducta única y un único delito cuando el funcionario público asesore o litigue un mismo asunto favoreciendo al mismo 'cliente', incluso en diversas ocasiones temporales, siempre y cuando los distintos actos parciales no pierdan el sentido jurídico y social de pertenecer a la misma gestión o asesoramiento ilegal (el mismo proceso, trámite o gestión), situación que no fue acreditada en el recurso de casación" (p. 14). Por el contrario, "no se advierte la existencia de un delito único precedido por la unidad de acción en sentido estricto, por varias razones: la primera es que, desde el punto de vista de la realización de las distintas conductas, no se aprecia una realización sucesiva y homogénea del mismo delito con identidad de objeto, modus operandi y estrechez temporal que, desde el punto de vista del sentido ontológico y normativo del tipo penal, permita adecuar un solo proceso o un mismo supuesto de hecho de asesoramiento y otras actuaciones ilegales, por parte de los condenados. La segunda, como de manera acertada lo señala la C.S.J., radica en que, incluso, si en gracia de discusión los actos parciales homogéneos y sucesivos de asesoría y litigio fueran susceptibles de ser abarcados por el mismo tipo penal, estos difícilmente podrían ser cubiertos por el mismo dolo, esto es, por la misma voluntad que le da sentido a los distintos actos parciales realizados por el autor" (p. 20). Y continúa: "La diversidad de actos, conceptos o demandas en distintos procesos judiciales carece de la homogeneidad necesaria para estructurar un único comportamiento. Ello implica negar, de igual manera, la unidad de la acción necesaria para configurar la existencia de un concurso ideal, precisamente, porque en este caso la pluralidad de tipicidades no se desprende de una unidad de acción, ni en sentido amplio ni estricto" (p. 21). Ello "impide configurar un delito continuado, justamente, por la carencia de identidad relativa de tipo, un modus operandi similar y un dolo global que le dé sentido de unidad a los actos realizados a partir del plan del autor. Lo que en definitiva se advierte es la presencia de un concurso real de delitos" (p. 21).

Sin embargo, las atinadas consideraciones de este autor no son trasladables a nuestro ordenamiento jurídico, porque el art. $441 \mathrm{CP}$ dice expresamente que la actividad profesional o de asesoramiento puede ser «permanente o accidental». Con lo 
cual nuestro legislador, a diferencia del colombiano, ha resuelto en el propio tipo penal dichos problemas al configurarlo como un delito eventualmente permanente (supra 6). Otra cosa es que desde el punto de vista de la proporcionalidad la solución legal no sea adecuada, pues impone la misma pena a un acto aislado que a una reiteración de actos. No obstante, pudiera plantearse la hipótesis de que si el funcionario trabaja para distintos "clientes" de modo permanente o accidental, podría apreciarse un concurso real de delitos. Sin embargo, esta hipótesis también hay que descartarla, porque el art. $441 \mathrm{CP}$ dice expresamente que la actividad profesional o de asesoramiento se tiene que hacer «bajo la dependencia o al servicio de entidades privadas o de particulares» (en plural). Con esta expresión no se quiere decir que haya que considerar impune la actividad profesional o el asesoramiento a una sola persona física o jurídica, sino que lo que implica es que cuando la conducta se lleve a cabo respecto de varias personas solamente habrá un único delito. Por tanto, respecto del art. $441 \mathrm{CP}$ español no cabe apreciar concurso homogéneo de delitos, ni tampoco el delito continuado ${ }^{141}$.

En cambio, no hay ningún inconveniente en admitir el concurso heterogéneo de delitos con las falsedades documentales, por ejemplo ${ }^{142}$. Sin embargo, en otros supuestos, dado

141 Así, la SAP Valencia (Secc. $1^{\text {a }}$ ) 252/2001, de 8 de octubre, al entender que "una pluralidad de actos ilícitos integran lo que legalmente se denomina «actividad», y esto excluye la posibilidad de apreciar un delito continuado". En contra, apreciando delito continuado, véanse las SSAP Barcelona (Secc. 21 $1^{\text {a) }}$ 718/2011, de 23 de mayo; Sevilla (Secc. 3a) 275/2007, de 1 de junio (por conformidad); la SJP de Orihuela 141/2016, de 8 de junio. La SJP n ${ }^{\circ} 4$ de Palma de Mallorca 178/2013, de 22 de mayo, confirmada por la SAP Baleares (Secc. 2a) 317/2014, de 17 de noviembre (caso Andratx II), condenó al Alcalde como autor de un delito continuado de negociaciones prohibidas del art. $441 \mathrm{CP}$ en relación con el art. 74.2 CP (sic) y también a un arquitecto como cooperador necesario en dicho delito continuado, pero con el atenuante del art. 65.3 CP.

142 Paradigmática, la SAP Cádiz (Secc. 3ª) 219/2011, de 8 de julio (caso operación Karlos), que también apreció un concurso medial con un delito conti- 
el carácter subsidiario de los delitos de peligro respecto de los de lesión, lo obligado será apreciar más bien un concurso aparente de leyes penales, con prevalencia de esos otros delitos sobre el art. $441 \mathrm{CP}$, como sucede con la prevaricación, la revelación de secretos, el cohecho, el tráfico de influencias o los fraudes y exacciones ilegales ${ }^{143}$. No obstante, si el específico abuso del cargo no comprende todo el peligro para la función pública generado por la actividad profesional o de asesoramiento, entonces podría apreciarse un concurso de delitos, como puede suceder, por ejemplo, con las negociaciones prohibidas del

nuado de estafa. La STS 636/2012, de 13 de julio, que la confirma, entiende que el delito del art. $441 \mathrm{CP}$ no quedaría absorbido por los delitos de falsedad y estafa, porque quedarían "flecos pendientes de antijuridicidad" (f.j. $7^{\circ} .4$ ), aunque le parece "un ejercicio de magnanimidad por parte de la $\mathrm{Au}$ diencia" haberlo incluido dentro de la fórmula concursal medial (f.j. $7^{\circ} .5$ ). Es frecuente en la jurisprudencia admitir el concurso con otros delitos. Por ejemplo, la STS 1189/2010, de 30 de diciembre, confirmó la condena por un concurso de delitos con amenazas, extorsión y descubrimiento y revelación de secretos; la STS 484/2008, de 11 de julio, confirmó un concurso de delitos con cohecho; la SAP Barcelona (Secc. 21 ${ }^{\text {a }}$ ) 718/2011, de 23 de mayo, apreció un concurso de delitos con el tráfico de influencias y con el uso de secreto o de información privilegiada; la SAP Cáceres (Secc. 2a) 9/2003, de 22 de octubre, con los delitos de malversación y amenazas; la SAP Zaragoza (Secc. 6a) 1/2014, de 14 de abril, con el delito de tráfico de influencias [si bien el STSJ Aragón (Sala Civil y Penal) 4/2014, de 16 de septiembre, anuló la condena por tráfico de influencias; confirmada por la STS 411/2015, de 1 de julio]; la SJP n ${ }^{\circ} 4$ Pamplona 251/2009, de 4 de junio, con el delito de prevaricación urbanística.

143 Como dicen Morales Prats/Rodríguez Puerta, en Quintero Olivares (dir.): Comentarios..., p. 1802: "El art. $441 \mathrm{CP}$ no exige ni la incidencia efectiva de la actividad privada en la resolución de asuntos públicos, ni un efectivo abuso de los conocimientos obtenidos del desempeño de funciones públicas. De este modo, de producirse una real incidencia en el ejercicio de funciones públicas vendrían en aplicación el delito de prevaricación, el de revelación de secretos o el delito tipificado en el artículo $439 \mathrm{CP}$, por citar algunos ejemplos. También podrían plantearse problemas de delimitación en algunos supuestos con el delito de cohecho". En el mismo sentido, García EsPa$\tilde{\mathrm{NA}}, J p D \mathrm{n}^{\circ} 48$ (2003), p. 65; MiR PUIG, Los delitos contra la Administración pública ..., cit., p. 368. La SAP Barcelona (Secc. $5^{\text {a) }}$ ) de 23 de febrero de 2000 , considera que estos delitos "presentan un carácter residual con relación al resto de figuras delictivas tipificadas en el Tít. XIX". 
art. $439 \mathrm{CP}^{144}$. "De este modo - dice Cugat MAuRI-, se castigaría el desarrollo continuado de la actividad profesional o empresarial al servicio de intereses privados ajenos a la función pública con permanente peligro para la objetividad, por un lado, y la participación en los asuntos de su competencia, con específico abuso del cargo, por otro"145.

\section{Penalidad}

En cuanto a las penas previstas en el art. $441 \mathrm{CP}$, aparte de la pena de multa de 6 a 12 meses, la reforma de 2015 ha elevado la pena de suspensión para empleo o cargo público ${ }^{146}$.

144 Castro Moreno, A.: "Negociaciones prohibidas a los funcionarios públicos y autoridades en Derecho penal", en La Ley penal no 22 (2005), p. 33, advierte de la confusión en la práctica entre ambas figuras delictivas.

La STS 119/2012, de 15 de marzo, apreció un concurso de delitos entre los arts. 441 y 439 CP. La AP Baleares había condenado por malversación (aspecto que anula la STS) y consideró que este delito absorbía el del art. $441 \mathrm{CP}$.

La STS 765/2014, de 4 de noviembre, califica, a efectos del principio acusatorio, de "un claro supuesto de homogeneidad descendente" la relación entre el art. 439 y el 441 CP. "Este último - dice- es el más general, mientras que el 439 requiere específicamente el aprovechamiento que en el 441 no se exige". También aprecia la homogeneidad entre ambas figuras delictivas la SAP Baleares (Secc. 2a) 317/2014, de 17 de noviembre (caso Andratx II).

145 Cugat Mauri, M.: "Negociaciones prohibidas", en F.J. Álvarez García (dir.), Tratado de Derecho penal español. Parte especial, t. III («Delitos contra las Administraciones Pública y de Justicia»), Valencia, 2013, p. 601, y añade: "del mismo modo que se considera que la utilización del arma ilícita no lleva a absorber la tenencia ilícita de armas en el asesinato, tampoco aquí se considera que la interferencia en los negocios públicos pueda absorber todo el desvalor de la dedicación continuada a actividades privadas paralelas al ejercicio del cargo, pues abarcando un lapso temporal superior al de la concreta interferencia en el negocio público, introducen una potencialidad lesiva para la función pública que no puede quedar abarcada por el delito que castiga el puntual abuso de la misma".

146 Valeije Álvarez, I.: "Negociaciones y actividades prohibidas a los funcionarios públicos y de los abusos en el ejercicio de su función (arts. 439 y ss.)", en J.L. González Cussac (dir.): Comentarios a la reforma del Código Penal de 2015, Valencia, 2015, p. 1219. 
Antes era de 1 a 3 años ${ }^{147}$, ahora es de 2 a 5 años, que sigue considerándose como pena menos grave.

Hubiese sido conveniente diferenciar a efectos penológicos entre que la actividad profesional o de asesoramiento sea de carácter «permanente o accidental» ${ }^{148}$. En el primer caso, parece más proporcionada una pena de inhabilitación, y probablemente (aunque ello exigiría un estudio más profundo comparando la previsión penológica de otros delitos de funcionarios) la pena de prisión, tal y como se propuso durante la tramitación parlamentaria de la reforma de $2015^{149}$. En el segundo caso, puede ser suficiente la pena de suspensión.

147 Veamos las penas que se impusieron en los casos que he destacado supra 9.4. La STS 362/2014, de 25 de abril (caso ITV Cataluña) impuso al Presidente de la Secc. $5^{\text {a }}$ de la Sala de lo contencioso-administrativo del TSJ de Cataluña una pena de suspensión de empleo o cargo público de 2 años y multa de 9 meses con una cuota de $50 €$ (en total $13.500 €$ ). La SAP Baleares (Secc. 2a) 394/2010, de 1 de diciembre (caso Andratx I), confirmó la condena al Director General de Ordenación del Territorio del Govern Balear de una suspensión de 2 años y seis meses y una multa de 9 meses con una cuota de $25 €$ (en total $6.750 €$ ). La SAP Baleares (Secc. 2a) 317/2014, de 17 de noviembre (caso Andratx II), confirmó la condena al Alcalde de una suspensión de 2 años y una multa de 12 meses con una cuota de $20 €$ (en total $7.200 €)$.

Estas penas son claramente insuficientes para prevenir esta clase de conductas.

148 Comparto la opinión de GarCía España, $J p D$ n $^{\circ} 48$ (2003), p. 64.

149 El Proyecto presentado en el Congreso que daría luz a la LO 1/2015 no preveía dicha elevación de pena. Se presentaron dos enmiendas en este sentido: 1) $\mathrm{La} \mathrm{n}^{\circ} 262$ presentada por el Grupo Parlamentario Vasco (EAJ-PNV), que asignaba penas de multa de uno a cuatro años y suspensión de empleo o cargo público por tiempo de dos a seis años; y 2) La n ${ }^{\circ} 755$ del Grupo Parlamentario Socialista, que asignaba una pena de prisión de seis meses a un año e inhabilitación especial para empleo o cargo público por tiempo de uno a tres años (BOCG-Congreso, Serie A, $\mathrm{n}^{\circ}$ 66-2, de 10 de diciembre de 2014, p. 182 y 490). En el Informe de la Ponencia se dice que ambas enmiendas fueron rechazadas (BOCG-Congreso, Serie A, $\mathrm{n}^{\circ} 66-3$, de 21 de enero de 2015, p. 42), pero en el Dictamen de la Comisión figura ya la redacción que finalmente fue aprobada (BOCG - Congreso, Serie A, $\mathrm{n}^{\circ} 66-4$, de 22 de enero de 2015, p. 89). Probablemente ello haya sido debido a una enmienda transaccional del Grupo Popular aprobada aprisa y corriendo en la sesión 
El problema que se plantea con la penalidad establecida en el art. $441 \mathrm{CP}$ es que puede resultar más benévola que la prevista en el régimen disciplinario de los empleados públicos. En efecto, el art. 95.2.n) EBEP considera como falta muy graves «el incumplimiento de las normas sobre incompatibilidades cuando ello dé lugar a una situación de incompatibilidad». Y el art. 96.1 EBEP prevé que se pueda imponer la separación del servicio para los funcionarios o el despido disciplinario para el personal laboral, es decir, lo que sería una inhabilitación; pero es que incluso la suspensión de funciones o de empleo y sueldo puede llegar a ser de hasta 6 años ${ }^{150}$. Esta cuestión de coordinación con las sanciones administrativas es un problema que excede del ámbito de esta figura delictiva y que exigiría una revisión general de las relaciones entre el Derecho penal y el Derecho administrativo sancionador, que es de extraordinaria complejidad, pero parece que la actual penalidad del art. $441 \mathrm{CP}$ no es correcta.

de 16 de enero de 2015 (DSCG - Congreso, X Legislatura, Comisión de Justicia, $\mathrm{n}^{\circ} 738$, de 16 de enero de 2015, p. 40-41). El diputado socialista, el Sr. DE la Rocha Rubí, se quejaba en esa sesión de la "urgencia y la aceleración irresponsable". Concretamente decía: "Ayer se nos entregaron de golpe cuarenta enmiendas transaccionales que reconozco -yo que soy, si se me permite la expresión, bastante currante- que aún no he podido ni siquiera ver en lo que me afecta... En el Código Penal tenemos que tener conciencia de que una coma o un año arriba o abajo en una pena afecta a miles de ciudadanos, y como legisladores, si somos perfectamente conscientes de lo que estamos haciendo en un tema concreto, no debemos hacerlo irreflexivamente" (ibídem, p. 14). Y más adelante dice: "Parece que en los textos que nos han entregado ayer, repito que aceleradamente y a última hora y que aún no hemos podido examinar con rigor, aceptan también incrementar las penas de algunos de estos delitos [se refiere a los delitos de corrupción]" (p. 16). Supongo que en ese momento es cuando apareció, sin debate parlamentario alguno, la actual pena de suspensión de 2 a 5 años.

150 Para los altos cargos la destitución implica que no podrán ser nombrados para ocupar otro alto cargo por un período de entre 5 y 10 años (art. 26.4 Ley $3 / 2015$ ), además conlleva la pérdida del derecho a percibir la compensación tras el cese y la obligación de restituir las cantidades percibidas en este concepto (art. 26.2 Ley 3/2015). 
Por ejemplo, en el caso del Presidente de la AP de Las Palmas, al que el TS finalmente absolvió, el acusado se enfrentaba a una pena máxima de 3 años de suspensión y multa de hasta 12 meses. Sin embargo, el régimen disciplinario judicial ya prevé para las infracciones muy graves sanciones de suspensión de hasta tres años (ahora inferior, pero en el momento de la comisión de los hechos igual que la pena del art. $441 \mathrm{CP}$ ), traslado forzoso a más de $100 \mathrm{~km}$, pero incluso está prevista la separación de la carrera judicial ${ }^{151}$, es decir, lo equivalente a una inhabilitación (art. 420.2 LOPJ).

Por echar la vista atrás, las penas previstas en los antecedentes legislativos del actual precepto fijaban una penalidad mucho mayor. Así, en el art. $198 \mathrm{CP} / 1944$ las penas que se preveían eran de inhabilitación especial de 6 años y 1 día a 12 años y multa de hasta 5.000.000 pesetas, y en el art. 493 PCP/1980, se preveía una suspensión de 2 a 6 años, pero para el caso de reincidencia dicha pena se convertía en inhabilitación especial por tiempo de 6 a 18 años.

También cabe señalar que en 2010 se cambió el plazo de prescripción de este delito, que pasó de los tres años a los cinco $(\text { art. } 131.1 \mathrm{CP})^{152}$.

\section{Conclusiones}

Los conflictos de intereses están en la base de muchos casos de corrupción de empleados públicos. Para hacerles frente se ha previsto un sistema de incompatibilidades que trata de garantizar la imparcialidad de éstos y la objetividad de los poderes

151 Delgado Gil, La Ley penal no 75 (2010), p. 76 n. 16, señala que el CGPJ acordó en su reunión plenaria del día 22 de abril de 2010 por unanimidad sancionar al magistrado con su separación definitiva de la carrera judicial como autor de cuatro faltas de las consideradas muy graves en el régimen disciplinario de la judicatura.

152 Apreciaron la prescripción, por ejemplo, la STS 92/1999, de 1 de febrero; el ATS de 22 de octubre de 2014 (caso ITV - pieza separada ${ }^{\circ} 3$ ); y la SAP Valencia (Secc. $5^{\text {a }}$ ) 138/2005, de 19 de abril. 
públicos. Los sistemas administrativos de control y sanción de los conflictos de intereses están fallando, por lo que la intervención penal en este ámbito está más que justificada. Sin embargo, la regulación vigente resulta insuficiente en cuanto a la penalidad prevista y al alcance del sujeto activo. El art. $441 \mathrm{CP}$ sólo se puede cometer durante el desempeño de un cargo público, por lo que se produce una laguna de punibilidad cuando la actividad profesional o de asesoramiento del funcionario se lleva a cabo después de haber cesado en el cargo. Para hacer frente al fenómeno de las puertas giratorias (pantouflage o revolving doors) que pueda comprometer la deseable objetividad de los poderes públicos, abogo, en vez de desincriminar las conductas del art. $441 \mathrm{CP}$ y dada la actual situación de fracaso del control administrativo de los conflictos de intereses, por potenciar aun más la intervención penal en este terreno y extender el ámbito del art. $441 \mathrm{CP}$ de un modo similar a como se ha hecho en Francia. Ahora bien, hay que hacer una interpretación restrictiva de este delito en atención al fin de protección de la norma, que es el principio de imparcialidad/objetividad, y delimitar el ilícito administrativo del ilícito penal en función de una interpretación teleológica y valorativa de todos los elementos del art. $441 \mathrm{CP}$. Ello nos lleva a concluir que la desaprobación penal de la actividad profesional o de asesoramiento incompatible con la función pública se determinará por la finalidad a la que sirve, que es la de obtener o conceder una ventaja o beneficio frente a los demás ciudadanos, poniendo así en peligro la imparcialidad de los empleados públicos y por ende la objetividad de los poderes públicos. 